\title{
Holocene moisture changes in western China, Central Asia, inferred from stalagmites
}

Yanjun Cai $^{1,2^{*}}$, John C. H. Chiang ${ }^{3}$, Sebastian F. M. Breitenbach ${ }^{4}$, Liangcheng Tan ${ }^{1,2}$, Hai Cheng $^{2,5}$, R. Lawrence Edwards ${ }^{5}$, Zhisheng $\mathrm{An}^{1,2}$

1. State Key Lab of Loess and Quaternary Geology, Institute of Earth Environment, Chinese Academy of Sciences, Xi'an 710061, China

2. Institute of Global Environmental Change, Xi'an Jiaotong University, Xi'an 710049, China.

3. Department of Geography and Berkeley Atmospheric Science Center, University of California, Berkeley CA 94720, USA

4. Department of Sediment- and Isotope Geology, Ruhr-Universität Bochum, Germany

5. Department of Earth Sciences, University of Minnesota, Minneapolis, MN 55455, USA

* corresponding author: State Key Lab of Loess and Quaternary Geology, Institute of Earth Environment, Chinese Academy of Sciences, Xi'an 710061, China; Email Address: yanjun_cai@ieecas.cn (Y.J.Cai)

\section{Abstract}

Central Asia lies at the convergence between the Mediterranean and Asian monsoon climates, and there is a complex interaction between the westerlies with the monsoon to form the climate of that region and its variability. The region is highly vulnerable to changes in rainfall, highlighting the need to understand the underlying controls. We present a stalagmite-based $\delta^{18} \mathrm{O}$ record from Kesang Cave in western China, using MC-ICP-MS U-series dating and stable isotope analysis. Stalagmite calcite $\delta^{18} \mathrm{O}$ largely documents changes in the $\delta^{18} \mathrm{O}$ of precipitation. $\delta^{18} \mathrm{O}$ in stalagmites was low during the early and middle Holocene (10.0-3.0 ka BP), and shifted to higher values between 3.0 and $2.0 \mathrm{ka} \mathrm{BP}$. After $2.0 \mathrm{ka} \mathrm{BP}, \delta^{18} \mathrm{O}$ fluctuates with distinct centennial-scale variations. Drawing from results of state-of-the-art atmospheric general circulation model simulations for the preindustrial period and $9 \mathrm{ka} \mathrm{BP}$, we propose that changes in moisture source regions and the wetter climate both contributed to the isotopic depletion of precipitation during the early and middle Holocene. Multiple records from surrounding regions indicate a generally wetter climate during the early and mid- Holocene, supporting our 
interpretation on the speleothem $\delta^{18} \mathrm{O}$. Changes in precipitation seasonality do not appear to be a viable explanation for the observed changes, nor increased penetration of monsoonal moisture to the study site. We speculate that the climatic regime shifted around 3.0-2.0 ka BP towards a drier climate, resulting in temperature having dominant control on precipitation $\delta^{18} \mathrm{O}$. The demise of three settlements around 500AD at the margin of Tarim Basin coincided with a period of decreased precipitation and increased temperature that likely affected local water resources, underscoring the potential impact of climate on human habitation in this region.

Keywords: Stalagmite, Central Asia, Oxygen isotopes, Westerlies, Asian monsoon, Moisture source, Precipitation seasonality, Temperature, Holocene

\section{Introduction}

The modern-day continental climate of Central Asia is dominated by the westerlies (Chen et al., 2008; Cheng et al., 2012). The Central Asian atmospheric circulation patterns play an important role in linking North Atlantic and Asian monsoon climates, and its desert regions contribute significantly to dust loadings over East Asia (Chiang et al., 2015; Porter and An, 1995; Sun et al., 2012; Zhang et al., 1997). The generally dry climate, dwindling water resources and fragile ecosystems make Central Asian communities highly vulnerable to changes in precipitation (Narisma et al., 2007; Qin et al., 2005; Sorg et al., 2012). Thus, understanding the causes of variability in the westerlies and interaction with the Asian summer monsoon is vital for the assessment of current and future water resource dynamics in Central Asia. The westerlies also play a fundamental role in aerosol distribution and dust deposition over East Asia. Well-dated and highly resolved palaeoclimate reconstructions from this region serve to put today's climate dynamics within a long-term perspective, and improve our capability to predict future climatic and hydrological changes.

Various palaeoclimate proxy studies inform our understanding of Holocene climate and environmental change in Central Asia (Han and Qu, 1992; Liu et al., 2008; Mischke and Wünnemann, 2006; Rudaya et al., 2009; Sun et al., 1994; Wang et al., 2013; Zhao et al., 2015; Zhong et al., 2010). Several syntheses (Chen et al., 2008; Herzschuh, 2006; Ran and Feng, 2013; 
Ricketts et al., 2001;) have been published over the last decade, providing valuable insights into Holocene moisture dynamics of this region. However, there are divergent viewpoints on Holocene moisture variability, of which three stand out. First, Chen et al. (2008) propose that westerlies-dominated arid Central Asia experienced regionally synchronous and coherent moisture changes during the Holocene. They argue that the moisture history of this region is outof-phase with that of monsoonal China, implying that moisture from southern monsoon sources did not reach Central Asia. The second view proposes that the moisture conveyed by the westerlies is not critical to environmental changes observed in Central Asia, but rather, the Asian monsoon contributed substantial moisture during the early and mid-Holocene (Mischke and Wünnemann, 2006; Rudaya et al., 2009; Zhong et al., 2010). A study on a lake record from Ili Valley, Xinjiang, China, suggests that climatic changes near Kesang Cave are generally similar to changes observed in Asian summer monsoon-governed regions since the last deglaciation ( $\mathrm{Li}$ et al., 2011). Third, Ran and Feng (2013) suggest that the early Holocene was generally dry and that a trend towards wetter conditions started only around $8.2 \mathrm{ka} \mathrm{BP}$, with the last $\sim 4 \mathrm{ka}$ marking the Holocene Optimum in terms of moisture conditions in the Xinjiang region.

The speleothem $\delta^{18} \mathrm{O}$ record from Kesang cave (Cheng et al., 2012) reflects $\delta^{18} \mathrm{O}$ of precipitation $\left(\delta^{18} \mathrm{O}_{\text {precip }}\right)$ and follows prominent precessional rhythms, with low $\delta^{18} \mathrm{O}$ values during high northern Hemisphere $(\mathrm{NH})$ insolation periods. Low $\delta^{18} \mathrm{O}_{\text {precip }}$ is at odds with modern-day observations that show a strong influence of temperature on $\delta^{18} \mathrm{O}_{\text {precip }}$ in this region (Aizen et al., 2006). This apparent contradiction may be resolved by intrusion of monsoon-related moisture from South Asia (Cheng et al., 2012) or, alternatively, by changes to the seasonal distribution of precipitation (Kutzbach et al., 2014).

These contradictory interpretations beg the question of what controls the hydrological cycle and moisture distribution across Central Asia. More precisely, what is the correct interpretation to changes in speleothem $\delta^{18} \mathrm{O}$ observed in Kesang Cave? To this end, we present radiometrically dated speleothem $\delta^{18} \mathrm{O}$ data from Kesang Cave. Our record confirms previously reported Holocene speleothem $\delta^{18} \mathrm{O}$ data (Cheng et al., 2012), and documents changes in $\delta^{18} \mathrm{O}_{\text {precip }}$ over the last thousand years in greater detail. We propose a comprehensive interpretation of speleothem $\delta^{18} \mathrm{O}$ in the context of climatic changes occurring in this region, with the aid of 
climate model simulations. Finally, we compare our record to regional archaeological records to show that the demise of ancient cities around the Tarim Basin coincided with a period of significant regional climate change around 400-600AD, suggesting that the precipitation change had influence on the societal changes in this area.

\section{Cave site and local climate}

Kesang Cave (N42 $52^{\prime}$, E81 ${ }^{\circ} 45^{\prime}, \sim 2,070 \mathrm{~m}$ a.s.1.) is located in Tekesi County, Xinjiang Autonomous Region of China (Fig. 1a). The host rock is Silurian limestone of Keketiekedaban group. The current cave air temperature is $\sim 4.9^{\circ} \mathrm{C}$, slightly higher than the mean annual temperature of $3.1^{\circ} \mathrm{C}$ at the Zhaosu Meteorological Station (N4310', E81 $08^{\circ}, \sim 1900 \mathrm{~m}$ a.s.1., $\sim 60 \mathrm{~km}$ northwest of the Kesang Cave) from 1957 to 2000. The mean annual meteoric precipitation at Zhaosu station is $500 \mathrm{~mm}$, with >80\% falling between April and September. Incave relative humidity was $88.4 \%$ in October 2010 when the cave was surveyed. The $\mathrm{CO}_{2}$ concentration in the cave was measured using a hand-held Vaisala carbon dioxide meter (M170GMP70). $\mathrm{CO}_{2}$ increased from 380 ppmv to 1120 ppmv from the entrance to the inner chamber, indicating relatively weak ventilation in the cave. The vegetation in the wider region around the cave site is dominated by alpine meadow and forest, while the hill in which the cave formed is at present covered by Picea obovata forest. Orographic uplift leads to adiabatic cooling of intruding air masses and elevated precipitation with altitude in the study area (Fig. 1b).

At present, the climate of semiarid-arid Central Asia is dominated by the westerlies (Aizen et al., 2006; Chen et al., 2008; Cheng et al., 2012). However, strong climatic diversity characterizes this region, in particular the seasonality of precipitation. The region at the western end of the transect from Kabul to Bishkek receives most of its annual precipitation during boreal winter (between October to April), while the eastern sector receives most annual precipitation during summer (from May to September, Fig. 1c) (Sorg et al., 2012). The stark difference in seasonal precipitation patterns between these two regions of Central Asia is largely determined by the geography, that is, the surrounding mountain chains. This, together with the interplay between the south-western branch of the Siberian anticyclone and westerly cyclonic activity determines the evolution of synoptic processes (Aizen et al., 1997; Wolff et al., 2016). 
The plains of Central Asia are open year-round to cold and dry northerly and north-westerly air masses, as well as moisture-bearing westerly inflow of air masses. The Himalaya, Pamir, Hindu Kush and Tian Shan mountain ranges almost completely isolate Central Asia from southerly and easterly low-level moisture-bearing air masses originating over the Indian Ocean (Schiemann et al., 2008). During summer, the northerly and north-westerly airflow causes cooling and strong winds, with dust storms and minimal precipitation over the vast plains. Further east, over the high rugged mountain ranges, westerly-derived air masses bearing recycled moisture are uplifted to produce orographic rainfall. In winter, the Siberian High forces a more southern track to the westerly cyclonic intrusions; they propagate across southern Central Asia from Iran and Afghanistan (South Caspian, Murgabic and Higher-Amudarya cyclones). As a result, increased precipitation (largely as snowfall) occurs over the Central Asia plains (Schiemann et al., 2008, and references therein). In addition, the west-to-east oriented Tian Shan Mountains mark an important climatic boundary in Central Asia: arid-desert climate characterizes its south (BWk climate according to the Koeppen classification, Peel et al., 2007), and arid-steppe climate prevails in the north (BSk, Peel et al., 2007). The Tian Shan Mountains act as important physical barrier that blocks cold airflow from the north in winter. Because of high sensitivity to hydroclimatic perturbations, our study area is ideal for studying the dynamics of the westerlies. On the other hand, this site is relatively unaffected by changes in winter cold flow from northern Siberia and Mongolia.

\section{Stalagmites and analytical methods}

Stalagmite samples CNKS-2, CNKS-3, CNKS-7 and CNKS-9 from Kesang Cave are used to establish the Kesang $\delta^{18} \mathrm{O}$ record, with two covering the entire Holocene and two covering the last 1200 years. All stalagmites were cut in halves along their growth axes and their surfaces polished. Fig. 2 illustrates the stalagmites used to establish the Kesang $\delta^{18} \mathrm{O}$ record, each with the

positions of ${ }^{230} \mathrm{Th}$ dates. Subsamples were drilled along growth axes and dated at the Minnesota Isotope Laboratory on the inductively coupled plasma mass spectrometer (Thermo Fisher NEPTUNE, Cheng et al., 2013). The chemical procedures used to separate the uranium and thorium for ${ }^{230}$ Th dating are similar to those described in Edwards et al. (1987). 
Subsamples for stable isotope analysis were collected in two ways: 1) for CNKS-2, CNKS-3 and CNKS-9, samples were milled from the polished half of the stalagmite at intervals of $100 \mu \mathrm{m}$ (CNKS-2, CNKS-9), $75 \mu \mathrm{m}$ (CNKS-3, 13.5-19.6 mm) and $50 \mu \mathrm{m}$ (CNKS-3, 0-13.5 mm) along the growth axis using a NewWave computer-controlled micromill; 2) for CNKS-7, a stalagmite slab with the cross section dimensions of $0.8 \times 0.5 \mathrm{~cm}$ was cut using a diamond saw and then sampling material was scraped off perpendicularly to the growth axis at a mean resolution of $\sim 20$ subsamples per mm. We analysed all subsamples collected through the first method and every third sample from the second method. A total of 1008 oxygen isotope samples were measured on an IsoPrime 100 mass spectrometer equipped with MultiPrep at the Institute of Earth Environment, Chinese Academy of Sciences. The international standard NBS19 and the interlaboratory standard TTB1 were run for every 10 to 15 samples and arbitrarily selected duplicate measurements were conducted every 10 to 20 samples, respectively, to check for homogeneity and reproducibility. All isotope values are reported in $\delta$ notation, the per mil deviation relative to the Vienna Pee Dee Belemnite (VPDB) standard $\left(\delta^{18} \mathrm{O}=\left[\left(\left({ }^{18} \mathrm{O} /{ }^{16} \mathrm{O}\right)\right)_{\text {sample }} /\left({ }^{18} \mathrm{O} /{ }^{16} \mathrm{O}\right)\right)_{\text {standard }}\right.$ $1) \times 1000]$ ). The standard results show that the external precision of both $\delta^{18} \mathrm{O}$ and $\delta^{13} \mathrm{C}$ analysis are better than $0.15 \%(2 \sigma)$.

\section{Results}

\subsection{The U/Th chronology}

A total of $37^{230}$ Th dates were obtained from the four stalagmites. The measured isotope ratios of uranium and thorium, the decay constants and the calculated ages are listed in Table 1. Here, we use the bulk earth value with $50 \%$ error, i.e., $4.4 \pm 2.2 \times 10^{-6}$, a value applied by Cheng et al. (2012), for the initial thorium correction. By using the COPRA framework (Breitenbach et al., 2012), we establish the chronology (depth-age models) for each stalagmite. For the stalagmite CNKS-3 we allocate 2010 AD (when we collected these samples) as the year of last deposition atop the stalagmite, within the error margins, and recalculate the chronology, which is shown as the grey line in Fig. 3. We tune the chronology of CNKS-2 to that of stalagmite CNKS-3 over the period from 1500-2010 AD, due to the large dating error at the top of CNKS-2. The resultant 
chronology is also shown as grey line. As shown in Fig. 3, all our tuning on the chronology lies well within the range constrained by the COPRA routine with the original dates.

The age models show that stalagmites CNKS-2 and CNKS-3 were deposited during the last 1200 years. The calculated chronologies of CNKS-7 and CNKS-9 indicate that these two stalagmites were deposited during most of the Holocene, i.e., CNKS-9 from $7.0 \mathrm{ka}$ BP to present and CNKS-7 from 10.0 ka BP to 1.0 ka BP. The calculated growth rates of these stalagmites vary from $1.8 \mathrm{~mm} / \mathrm{ka}$ to $37.8 \mathrm{~mm} / \mathrm{ka}$, with mean growth rates of $18.3 \mathrm{~mm} / \mathrm{ka}, 18.9 \mathrm{~mm} / \mathrm{ka}, 6.9 \mathrm{~mm} / \mathrm{ka}$ and $10.6 \mathrm{~mm} / \mathrm{ka}$ for stalagmites CNKS-2, CNKS-3, CNKS-7 and CNKS-9 respectively. The observed variability in mean growth rates implies that the growth-controlling mechanisms (e.g. drip water supply, degree of drip water supersaturation, $\mathrm{CO}_{2}$ degassing) differed for these stalagmite samples.

\subsection{Test of equilibrium deposition}

Variations in stalagmite calcite $\delta^{18} \mathrm{O}\left(\delta^{18} \mathrm{O}_{\mathrm{c}}\right)$ could be ascribed to changes in drip water $\delta^{18} \mathrm{O}$ (amount weighted isotopic composition of meteoric precipitation), cave temperature (which is usually dominated by surface temperature), and physical processes of kinetic loss of $\mathrm{CO}_{2}$ and possibly evaporation of water during calcite deposition. Only if calcite has been deposited under

(near-)isotopic equilibrium conditions can the variations in $\delta^{18} \mathrm{O}_{\mathrm{c}}$ be used to infer past changes in cave temperature and the isotopic composition of infiltrating water. Replication is an effective test for the fidelity of speleothem isotope time series as palaeoclimate reconstructions (Dorale et al., 1998; Dorale and Liu, 2009; Wang et al., 2001a;). While it cannot strictly be ruled out that kinetic fractionation affects multiple replicating records equally (which would thus pass the replication test), the likelihood of kinetic fractionation is lower in well-replicating systems. If we consider differences in temporal resolution and dating uncertainties, the $\delta^{18} \mathrm{O}$ time series of CNKS-7 and CNKS-9 show significant similarities during the contemporaneous growth interval of 7.0-1.0 ka BP (as shown in Fig. 5), and the $\delta^{18} \mathrm{O}$ records from CNKS-2 and CNKS-3 show remarkable similarities during the overlapped growth period of 1.2-0.0 ka BP (as shown in Fig. 8). Our records are also similar to the $\delta^{18} \mathrm{O}$ record reported by Cheng et al. (2012) (as shown in Fig. 5). The replication of all these records suggests that the stalagmites were likely deposited 
under conditions limiting isotopic disequilibrium. Moreover, the $\delta^{13} \mathrm{C}$ profiles of our four stalagmites show consistent variations during the overlapping period (Fig. 4) and can be used as another replication test for the isotopic equilibrium deposition. Therefore, the $\delta^{18} \mathrm{O}$ signal recorded in these four stalagmites is considered primarily of climatic origin and dictated by changes in the $\delta^{18} \mathrm{O}$ in precipitation and cave temperature without significant kinetic fractionation (Hendy, 1971).

\subsection{The $\delta^{18} \mathrm{O}$ and $\delta^{13} \mathrm{C}$ records}

Micromilling resulted in a mean temporal resolution of 7.0 years, 3.3 years and 14.9 years for stalagmites CNKS-2, CNKS-3 and CNKS-9 respectively, whereas $\sim 50$ years resolution has been attained for stalagmite CNKS-7 by using the manual scraping method. As shown in Fig. 5, the speleothem calcite $\delta^{18} \mathrm{O}_{\mathrm{c}}$ varied 5.5\% between -12\%o and -6.5\%o over the last 10,000 years, with generally low values during the early and middle Holocene and high values thereafter. We divided the Holocene record into three intervals: 10.0-3.0 ka BP, 3.0-2.0 ka BP, and 2.0 ka BP present, respectively, according to the observed variations in speleothem $\delta^{18} \mathrm{O}_{c}$, including the record obtained by Cheng et al. (2012):

i) $10.0-3.0 \mathrm{ka} \mathrm{BP} . \delta^{18} \mathrm{O}_{\mathrm{c}}$ values oscillate around $-10.4 \%$ with an amplitude of $2.5 \%$, and most being smaller than $-9.7 \%$. Three intervals within this phase (centred around 9.15 $\pm 0.8,5.75 \pm 1.9$ and $3.4 \pm 0.4 \mathrm{ka} \mathrm{BP}$ ) are characterized by relatively depleted $\delta^{18} \mathrm{O}$ values, while two others show higher $\delta^{18} \mathrm{O}$ values (8.3-7.2 and 4.3-3.8 $\left.\mathrm{ka} \mathrm{BP}\right)$.

ii) 3.0-2.0 ka BP. This interval represents a transition phase from (i) to (iii). $\delta^{18} \mathrm{O}_{\mathrm{c}}$ shows a clear increasing trend, accompanied by three centennial-scale oscillations.

iii) $2.0 \mathrm{ka} \mathrm{BP}$-present. The $\delta^{18} \mathrm{O}_{\mathrm{c}}$ values fluctuate around $-8.3 \%$ with an amplitude of $3.2 \%$ and do not show a clear long-term trend. Compared with interval (i), i.e. 10.0-3.0 ka BP, the amplitude of $\delta^{18} \mathrm{O}_{\mathrm{c}}$ fluctuations in this period is much larger, that is, $3.2 \%$ o versus $2.5 \%$, with most values being $>-9.7 \%$.

Speleothem calcite $\delta^{13} \mathrm{C}$ varied $6.8 \%$ between $-8.6 \%$ and $-1.8 \%$ over the last 10,000 years, with generally high values during the early Holocene and low values in the late Holocene, showing a long-term decreasing trend in general (Fig. 4a). It's worth noting that multiple short-term 
oscillations are found, with amplitudes of $\sim 2.0 \%$ in the early Holocene and up to $\sim 3.0 \%$ in the late Holocene.

\section{Discussion}

\subsection{Interpretation of speleothem calcite $\delta^{18} \mathrm{O}$}

Under isotopic equilibrium conditions, the $\delta^{18} \mathrm{O}$ of speleothem calcite is a function of the cave temperature and the $\delta^{18} \mathrm{O}$ signature of the parent drip water (Hendy, 1971). The temperaturedependent fractionation between the calcite and water $\left(-0.23 \%{ }^{\circ} \mathrm{C}\right.$, Kim and O'Neil, 1997) is relatively small and that Holocene temperature is estimated to have been higher by only about 2.5-3.0 ${ }^{\circ} \mathrm{C}$ between 10-8.0 ka BP relative to modern values, and then decreased gradually 1.5$2.0^{\circ} \mathrm{C}$ since $8.0 \mathrm{ka} \mathrm{BP}$ (Fang and Hou, 2011; Wang et al., 2001b). Given these, the largest portion of the observed $\delta^{18} \mathrm{O}_{\mathrm{c}}$ variation $(\sim 5.5 \%$ ) over the Holocene is most likely dominated by changes in drip water $\delta^{18} \mathrm{O}$, which is constrained by the amount weighted annual precipitation $\delta^{18} \mathrm{O}\left(\delta^{18} \mathrm{O}_{\mathrm{p}}\right)$. It is important to note that we cannot strictly exclude any influence of temperature on $\delta^{18} \mathrm{O}_{\mathrm{c}}$, because higher temperature during the early-mid Holocene might have lowered $\delta^{18} \mathrm{O}_{\mathrm{c}}$, while lower late Holocene temperature might have increased $\delta^{18} \mathrm{O}_{\mathrm{c}}$, thus increasing the total amplitude of the Holocene $\delta^{18} \mathrm{O}_{c}$ change. We argue however that changes in $\delta^{18} \mathrm{O}_{\text {precip }}$ related to changes in source and amount of precipitation outweighed potential changes associated with temperature dynamics.

Modern observations reveal a strong positive correlation between precipitation $\delta^{18} \mathrm{O}$ and air temperature on seasonal to decadal timescales in Central Asia (Aizen et al., 2006; Cheng et al., 2012) and the northern Tibetan Plateau (Thompson et al., 1989, 1997), suggesting temperature as the principle governing factor controlling present-day variations in $\delta^{18} \mathrm{O}_{\mathrm{p}}$. This implies that speleothem $\delta^{18} \mathrm{O}_{\mathrm{c}}$, which is dictated by $\delta^{18} \mathrm{O}_{\mathrm{p}}$, largely reflects local temperature changes, with elevated $\delta^{18} \mathrm{O}$ values indicating increased air temperature under current climate conditions. This notion however is incompatible with changes observed in speleothem $\delta^{18} \mathrm{O}_{\mathrm{c}}$ from Kesang Cave, which indicate low $\delta^{18} \mathrm{O}_{\mathrm{p}}$ in the early and middle Holocene (Fig. 5), relative to increased $\delta^{18} \mathrm{O}_{\mathrm{p}}$ in the late Holocene. A temperature control on $\delta^{18} \mathrm{O}_{\mathrm{p}}$ would imply that summertime temperatures 
were lower than today (recall that Kesang Cave has a summer rainy season). This interpretation would directly contradict our understanding of current conditions, where summertime temperatures should increase with northern hemisphere summer insolation. This disparity suggests that fundamental changes must have occurred in the relationship between $\delta^{18} \mathrm{O}_{\mathrm{p}}$ and local climate (Cheng et al., 2012) in the early and mid-Holocene. Below, we explore some potential causes.

\subsubsection{Penetration of Asian summer monsoon moisture into Central Asia.}

Han and Qu (1992) proposed that during the mid-Holocene the Asian summer monsoon front might have reached north of the eastern Tian Shan, as mirrored by high lake levels in Barkol Lake. Winkler and Wang (1993) proposed that a strong early Holocene summer monsoon reached the Altai Mountains, a region far northwest of the studied cave site. Jiang et al. (2007) also suggested that monsoonal rainfall may have been a significant moisture source for the Wulungu lake around 6 ka BP. Lacustrine sequences from lake Issyk-Kul (Ricketts et al., 2001), Boston Lake (e.g., Mischke and Wünnemann, 2006) and Hoton Nuur (Rudaya et al., 2009) indicate humid conditions during the early and middle Holocene, and also linked them to the penetration of the Asian monsoon deep into Eurasia. The $500 \mathrm{ka}$ speleothem $\delta^{18} \mathrm{O}$ record from Kesang Cave (Cheng et al., 2012) shows that $\delta^{18} \mathrm{O}_{\mathrm{p}}$ was much depleted at times of high northern hemisphere summer insolation (NHSI) compared to intervals of low NHSI, a behaviour closely resembling speleothem records in Asian summer monsoon regions (Cai et al., 2015; Wang et al., 2008).

Analysis of modern climate in Xinjiang suggests that summertime rainfall in Xinjiang varies in response to the west Asian subtropical westerly jet (WASJ). A southward shift of the WASJ favours warm and wet air penetrating from low south-westerly latitudes into Central Asia and Xinjiang, leading to increased indirect moisture transport from the Indian Ocean and higher rainfall (Zhao et al., 2014a, 2014b). Zhao et al. (2014b) further argue that increased summer precipitation in Xinjiang is potentially linked with a weakened Indian summer monsoon (ISM). A weakened ISM may lead to middle and upper tropospheric cooling over Central Asia, which in turn induces a southward shift of the WASJ over western and Central Asia. Moreover, with less 
moisture feeding the ISM, more moisture can be diverted to Central Asia (Zhao et al., 2014b). However, this specific mechanism - a southward WASJ shift from a weakened ISM, leading to increased monsoonal moisture into Central Asia - appears to contradict our current understanding that the ISM was stronger during the early and mid-Holocene relative to today (Cai et al., 2012; Fleitmann et al., 2007). The mechanism proposed by Zhao and co-workers $(2014 b)$ is based on analysis of modern-day inter-annual variability, which may not be an appropriate analogue for early to mid-Holocene climate conditions. Moreover, early and middle Holocene circulation patterns might have significantly differed from that of today. Thus, it appears unlikely that the penetration of South Asian moisture explains the depletion of $\delta^{18} \mathrm{O}_{\text {precip }}$ and wetter climate during the early and middle Holocene in Central Asia.

\subsubsection{Changes to precipitation seasonality.}

Winter precipitation, which in Xinjiang occurs largely as snow, is characterized by very low $\delta^{18} \mathrm{O}_{\mathrm{p}}$ (e.g. Wolff et al., 2016). Thus, an increase in the fraction of winter precipitation would

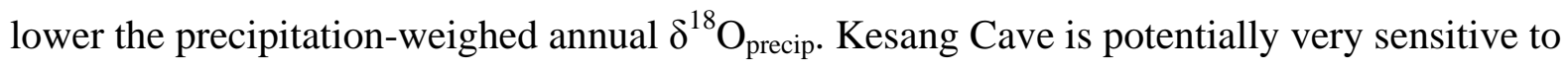
seasonal changes as it is located close to the boundary between summer precipitation dominance and winter precipitation dominance as one moves from east to west (Fig. 1c). A relatively small eastward shift in this seasonality boundary would change precipitation seasonality from a summer rainfall-regime to a winter snowfall-dominated one at Kesang Cave, resulting in depleted precipitation and drip water $\delta^{18} \mathrm{O}$ values. Climate model simulations by Kutzbach et al. (2014) suggest that winter precipitation increases in Central Asia during periods of maximum Northern Hemisphere seasonality (summer perihelion, winter aphelion); this lends some model support to the interpretation of oxygen isotope changes in the Kesang record. A strengthening of winter precipitation has also been evoked to explain low $\delta^{18} \mathrm{O}$ values at other locations, such as the Eastern Mediterranean during precession minima and summer insolation maxima (BarMatthews et al., 1997, 2003; Tzedakis, 2007). However, simulations with the Community Climate System Model version 3 (CCSM3) carried out by Kutzbach et al. (2014) did not reveal any significant regime shift, thus not lending model support to the above hypothesis. It is possible that the topography has a stronger control over the pattern of seasonal precipitation distribution in this region, limiting the response of the regime boundary to precession-induced 
climatic and environmental changes. Alternatively, the relatively coarse resolution $\left(3.75^{\circ}\right.$ in latitude/longitude grid) in their simulations may be insufficient to resolve small spatial shifts, and higher-resolution model simulations will be needed to test this hypothesis.

\subsubsection{Changes in the isotope composition of moisture sources.}

$\delta^{18} \mathrm{O}_{\text {precip }}$ integrates various processes in the hydrological cycle, such as water vapour source dynamics influenced by evaporation and transpiration, horizontal and vertical mixing, as well as phase transitions among ice, liquid, and vapour (Breitenbach et al., 2010; Dansgaard, 1964; Risi et al., 2008). Central Asia receives its moisture largely from re-evaporation (that is, recycling) from surrounding areas, and thus depends on locality and season of the westerlies and the ISM. Comparing the synoptic climatology and meteorological data with $\delta^{18} \mathrm{O}$ and deuterium excess in firn cores from the Tian Shan, Aizen et al. (2006) found that precipitation in Central Asia/western China is mainly derived from recycled moisture from the Aral-Caspian basin ( 54\%), and the Mediterranean and Black Seas ( 33\%), with only a small fraction ( 13\%) originating from the North Atlantic realm. This finding suggests that changes in the isotopic composition of these western basins may influence $\delta^{18} \mathrm{O}_{\text {precip }}$ in Central Asia.

Speleothem $\delta^{18} \mathrm{O}$ from the eastern Mediterranean, the $\delta^{18} \mathrm{O}$ record derived from G. ruber from the Eastern Mediterranean Sea, and the $\delta^{18} \mathrm{O}$ record of lake aragonite from Dead Sea Basin all indicate that $\delta^{18} \mathrm{O}$ in precipitation decreased during high northern hemisphere summer insolation periods, whereas wintertime precipitation amount increased (Almogi-Labin et al., 2009; BarMatthews et al., 1997, 2003; Cheng et al., 2015; Kolodny et al., 2005; Torfstein et al., 2009) reflecting intensified winter storm tracks (Kutzbach et al., 2014). Stronger westerlies would have carried moisture from more westerly sources, resulting in lower surface water $\delta^{18} \mathrm{O}$ in the reevaporation regions feeding Kesang Cave during these intervals. Such change should be reflected in a shift to a wintertime precipitation regime. Simultaneously, an intensified Indian summer monsoon would lead to depleted $\delta^{18} \mathrm{O}_{\text {precip }}$ in the southern Tibetan Plateau (Cai et al., 2010,2012 ), potentially complicating the interpretation of speleothem-based $\delta^{18} \mathrm{O}$ by adding ${ }^{18} \mathrm{O}-$ depleted moisture during summer. 
It is thus likely that the depletion of $\delta^{18} \mathrm{O}_{\text {precip }}$ at our study site during high NHSI reflects changes in water vapour $\delta^{18} \mathrm{O}$ from its source regions. Furthermore, generally wetter climate conditions may lead to higher relative humidity around the cave site, reducing re-evaporation of raindrops and isotopic enrichment of $\delta^{18} \mathrm{O}_{\text {precip }}$ during rain events, as demonstrated in northern China (Lee and Fung, 2008; Lee et al., 2012).

To explore this further, we analyse two simulations for the preindustrial period ( $0 \mathrm{ka})$ and $9 \mathrm{ka}$ BP, using the Community Atmosphere Model 5 (CAM5, Hurrell et al., 2013) at the standard $0.9^{\circ} \times 1.25^{\circ}$ resolution, and coupled to a slab ocean. We used standard CMIP5 preindustrial boundary conditions, and the $9 \mathrm{ka} \mathrm{BP}$ simulation differs from the 0 ka simulation only in that the calendar date was set to $-7000 \mathrm{AD}$, and methane level set to $650 \mathrm{ppb}$; ice sheet boundary conditions were kept to preindustrial. Both simulations were performed as part of a study of the Holocene East Asian summer monsoon by Kong et al. (2016), and we refer the reader to that reference for details of the model simulations.

The preindustrial CAM5 simulated climatology resembles today's summer-dominated precipitation seasonality at the grid point closest to Kesang Cave $\left(81.75^{\circ} \mathrm{E}, 42.9^{\circ} \mathrm{N}\right.$, Fig. $\left.6 \mathrm{~b}\right)$, and it also simulates the observed boundary in precipitation seasonality over Central Asia between the winter-dominated west and the summer-dominated east (Fig. 6a). The transition is located at ca. $73^{\circ} \mathrm{E}$, in agreement with observation. The simulated early spring rainfall near Kesang Cave is dominated by large-scale precipitation presumably from orographic uplift, whereas later in the spring and summer precipitation becomes convective in nature (not shown). The 9 ka simulation indicates that precipitation seasonality remains intact across the region, with the western segment remaining winter-, and the eastern segment summer-dominated. However, rainfall seasonality in the summer-dominated eastern region shows a shift of the rainfall season to a slightly later date. Over the Kesang grid point, rainfall is reduced in April (mostly due to reduced large-scale precipitation) and increased during the peak summer months (due to increased convective precipitation) in the Holocene thermal maximum simulation (Fig. 6b). Thus, these simulations appear to eliminate changes in precipitation seasonality (point 2 above) as a viable explanation for the observed early Holocene Kesang $\delta^{18} \mathrm{O}$ pattern; rather, topography exerts dominant control on precipitation seasonality in this region. 
Decreased April rains in the 9 ka simulation can be explained by a colder and drier atmosphere upwind of Kesang over western Central Asia, forced by prevailing northerly low-level winds (note that winter $\mathrm{NH}$ insolation is lower at $9 \mathrm{ka} \mathrm{BP}$ ). On the other hand, peak summer months were wetter because higher NH summer insolation led to widespread warming of the entire Central Asian/Tibetan Plateau region (Fig. 7a). Atmospheric moistening over Kesang Cave is also reflected over the entire region; the prevailing zonal moisture transport to Kesang increased by ca. $20 \%$ and meridional transport by ca. $40 \%$, broadly consistent with the modelled moister atmosphere (not shown). They suggest increased penetration of monsoonal moisture deep into the Tarim basin region, relating to point 1 above as a potentially viable explanation for the dynamics in the speleothem record. However, if we take the simulations simply at face value that neither amount nor seasonality of precipitation over Kesang changed fundamentally - it is implausible that increased penetration of monsoonal moisture can fully explain the speleothem $\delta^{18} \mathrm{O}$ record with its large change of 5.5\%.

Given that the simulations appear to eliminate both scenarios (1) and (2) above as the primary cause, we are left with changes in the isotopic composition of the source moisture as the potential remaining explanation. Indeed, a recent study by Battisti et al. (2014) appears to support this mechanism: their isotope-enabled simulations indicate significant shifts to lower June-August precipitation-weighed $\delta^{18} \mathrm{O}$ over north-eastern Africa and the Arabian Peninsula (by 4-5 \%o), Persia (by 2-3 \%o), and the Tibetan Plateau (by 4-7 \%o) from a low NH insolation forcing (207 ka BP) to a high NH insolation forcing (218 ka BP) [see Fig. 8b of Battisti et al., 2014]. The authors argue that the main reason for this change is a corresponding depletion in the imported water vapour into these regions. Whether such depletion of the source moisture is due to changes in source water composition, temperature, humidity, or changes in Rayleigh processes along the transport pathway remains to be studied in greater detail.

What does this imply for the Kesang Cave record? We note that the isotopic changes of precipitation in the simulations in Battisti et al. (2014) did not match the orbital signal at Kesang Cave, possibly due to the relatively coarse model resolution. The authors also point to other potential model shortcomings, including incorrect storm track position and model errors in 
fractionation at low temperatures. That being said, summertime moisture over Kesang Cave remained primarily derived from re-evaporation upstream: according to the 9 ka simulation, the majority of the moisture came directly from westerly sources, including the Aral-Caspian basin, the Mediterranean and the Black Sea (Fig. 7b), where surface water was depleted in the early and middle Holocene (e.g., Almogi-Labin et al., 2009; Bar-Matthews et al., 1997, 2003; Cheng et al., 2015; Kolodny et al., 2005; Torfstein et al., 2009). An appreciable fraction of precipitation over Kesang Cave is also derived from re-evaporation over the Tibetan Plateau to the south, where lighter $\delta^{18} \mathrm{O}$ has been found in both speleothems (Cai et al., 2012) and models (Battisti et al., 2014) (Fig. 7c). Moisture that was strongly depleted at the original source and subsequently recycled and transported to Kesang Cave during summer has the potential to retain the observed depleted early-mid Holocene $\delta^{18} \mathrm{O}$ values, as long as the depletion in ${ }^{18} \mathrm{O}$ at the first moisture source exceeds the enrichment during recycling. Reconstructions from Peqiin Cave, Northern Israel (Bar-Matthews et al., 2003) and Jeita Cave, Lebanon (Cheng et al., 2015) show that the precipitation in the Eastern Mediterranean was depleted in ${ }^{18} \mathrm{O}$ during the period from $\sim 10.0 \mathrm{ka}$ $\mathrm{BP}$ to $\sim 7.5 \mathrm{ka} \mathrm{BP}$ and subsequently enriched gradually to $\sim 4.5 \mathrm{ka} \mathrm{BP}$, while $\delta^{18} \mathrm{O}$ in the Asian monsoon realm (Dongge Cave, Southern China, Wang et al., 2005) increased gradually since $\sim 7.0 \mathrm{ka} \mathrm{BP}$ to $\sim 2.0 \mathrm{ka} \mathrm{BP}$ (Fig. 5). The long-term increasing trend likely indicate the regional responses of Mediterranean and Asian summer monsoon climates to insolation changes during the Holocene. The difference in timing of these changes suggests the divergence of regional climate system responding to the global climate change. In general, the Kesang $\delta^{18} \mathrm{O}$ record shows much similarity to these two records from west and east during the early period of $\sim 10.0$ $\sim 4.3 \mathrm{ka} \mathrm{BP}$, but differs significantly after $4.0 \mathrm{ka}$ BP for about 1000 years, when the Kesang $\delta^{18} \mathrm{O}$ values decreased. We hypothesize that this depletion might be partly caused by increased contribution/fraction of recycled moisture supply from surrounding glaciers, lakes and rivers supplied by glacier meltwater which was much depleted in ${ }^{18} \mathrm{O}$, while moisture source region got dried and moisture supply decreased remarkably. Alternatively, a combined effect of cooler temperatures and reduced summer precipitation due to aridification of surrounding moisture source regions could also result in more negative $\delta^{18} \mathrm{O}$ (see also Wolff et al., 2016). A definitive resolution of this issue will require high-resolution simulations with isotope-enabled climate models. 
Temperature is likely the major factor influencing $\delta^{18} \mathrm{O}$ in precipitation at our cave site over the last 2000 years, in accordance with modern observations (Aizen et al., 2006). However, temperature dependent fractionation of $0.55 \%$ per degree at mid latitudes (Dansgaard, 1964) cannot account for the large amplitude of speleothem $\delta^{18} \mathrm{O}$ changes (ca. 3.5\%), because temperature dependent fractionation between calcite and dripwater is negatively correlated with temperature (ca. $-0.23 \%{ }^{\circ} \mathrm{C}$, Kim and O’Neil, 1997), and cancels ca. half of the temperature impact on the precipitation $\delta^{18} \mathrm{O}$. Below-cloud evaporation during precipitation may amplify the temperature effect as high temperature may accelerate evaporation substantially (Lee et al., 2012), leading to increased temperature dependent fractionation (e.g. $0.75 \% /{ }^{\circ} \mathrm{C}$ at Hetian, Johnson and Ingram, 2004). Evaporation before infiltration into the epikarst system could further elevate $\delta^{18} \mathrm{O}$ of soil- and drip water. All these factors act in the same direction and would amplify the temperature effects on drip water $\delta^{18} \mathrm{O}$ and thus speleothem $\delta^{18} \mathrm{O}$. In this complex pattern speleothem $\delta^{18} \mathrm{O}$ likely reflects temperature during the last $\sim 2000$ years, with high $\delta^{18} \mathrm{O}$ signifying elevated temperature and vice versa. This explanation invokes a shift from a strong moisture composition influence, to a temperature forcing on $\delta^{18} \mathrm{O}_{c}$, which likely occurred during the period from $\sim 3.0 \mathrm{ka}$ to $\sim 2.0 \mathrm{ka} \mathrm{BP}$.

\subsection{Holocene climate change recorded in Kesang Cave and comparison with other proxy records}

We have argued that low speleothem $\delta^{18} \mathrm{O}$ values observed in the Kesang record indicate moister climate conditions during the early and middle Holocene (10-3 ka BP), whereas since ca. $2 \mathrm{ka}$ BP the generally high $\delta^{18} \mathrm{O}$ values reflect regional temperature variability. This inference is corroborated by the fact that over the last $500 \mathrm{ka}$ most interglacial speleothem growth intervals in Kesang Cave began with low $\delta^{18} \mathrm{O}$ values (Cheng et al., 2012). Lake sediments from the nearby sites largely indicate a relatively wet early and middle Holocene with the exception of Sayram Lake (Jiang et al., 2013, Fig. 5). For example, multi-proxy records from lake Issyk-Kul suggest a wet early Holocene, followed by more arid conditions (Rasmussen et al., 2001; Ricketts et al., 2001). Pollen deposition rates and the Artemisia to Chenopodiaceae ratio from Manas Lake indicate desert steppe vegetation between $10.5 \mathrm{ka} \mathrm{BP}$ to $9.0 \mathrm{ka} \mathrm{BP}$, and after $4.2 \mathrm{ka} \mathrm{BP}$, whereas steppe vegetation developed in the intervening period, implying relatively humid conditions in 
the early and middle Holocene (Sun et al., 1994). Boston lake, located east of the cave site, documented rising lake levels starting $\sim 8.2 \mathrm{ka} \mathrm{BP}$ and reaching a maximum $\sim 7.0 \mathrm{ka} \mathrm{BP}$, with subsequent gradually decline (Huang et al., 2009; Wünnemann et al., 2006). In particular, the sedimentary profile from Yili Valley, close to Kesang Cave, shows lacustrine sediments for the early and middle Holocene, but loess deposits since $\sim 3 \mathrm{ka} \mathrm{BP}$, again indicating a shift to drier conditions at $\sim 3 \mathrm{ka} \mathrm{BP}$ ( $\mathrm{Li}$ et al., 2011). The pollen record extracted from this profile also revealed two fluctuations between humid and relatively dry conditions during the early and middle Holocene, following a pattern similar to our $\delta^{18} \mathrm{O}$ record, considering the chronological uncertainties.

Our inference differs to some degree from the regional synthesis by Chen et al. (2008) and is largely opposite to the synthesis by Ran and Feng (2013). Inconsistencies between speleothem and lake sediments can be attributed to the fact that different proxies record different aspects of the hydrological cycle. Changes in lake levels and pollen assemblages used in these studies are mainly indicative of variations of effective moisture, which includes evaporative loss in addition to precipitation. Additionally, local geomorphological configurations may impact meltwater supply to these lakes, potentially resulting in differences in apparent water supply, since meltwater plays a major role in influencing lake levels in this region (Kaser et al., 2010).

Furthermore, the two syntheses cover different regions. Chen et al. (2008) used sediment cores from a vast region extending from $43.20^{\circ} \mathrm{E}$ to $117.38^{\circ} \mathrm{E}$ in arid Central Asia, while Ran and Feng (2013) used only sediment cores from north-western China (from $81.20^{\circ} \mathrm{E}$ to $94.2^{\circ} \mathrm{E}$ ). Although an average moisture index is good at producing a regionally representative picture, it smoothens details characteristic to individual sites. To obtain a meaningful regional average, all proxy indices should record the same aspect of climate, and reconstructions for a particular region demonstrate a geographically coherent trend. Fig. 1c shows that precipitation seasonality changes from west to east, implying that atmospheric circulation and precipitation dynamics differ in these two regions (Sorg et al., 2012). It suggests that one cannot directly compare and average the different records from western and eastern Central Asia. It is therefore unwise to interpret the entirety of records between the eastern Mediterranean region and western China using a single mechanism. 
Generally wetter conditions in western Central Asia (with dominant winter precipitation) and eastern Central Asia (with dominant summer precipitation) (Bar-Matthews et al., 2003; Chen et al., 2008; Cheng et al., 2012; Herzschuh, 2006; Li et al., 2011;) is established for the early and mid-Holocene. Wetter conditions in both regions may be caused by precession-related forcing of seasonal NH insolation changes, as suggested by Kutzbach et al. (2014). Increased precipitation in western Central Asia was likely caused by enhanced wintertime westerly storm tracks (Kutzbach et al., 2014), whereas increased humidity, higher rainfall and reduced evaporation in summer in eastern Central Asia might be linked to intensified moisture transport from the AralCaspian basin, Mediterranean Sea and North Atlantic (Chen et al., 2008), and possibly from regions affected by the Asian summer monsoon (Cheng et al., 2012).

From $\sim 3.0$ to $-2.0 \mathrm{ka} \mathrm{BP}$, stalagmite $\delta^{18} \mathrm{O}$ increases to a mean $\delta^{18} \mathrm{O}$ value about 2.0 permil higher than in the early and mid-Holocene. This prominent shift suggests that the region's climate changed from a relatively humid regime to noticeably drier conditions. Late Holocene conditions facilitated enhanced evaporation from the surrounding basins, progressively reducing moisture availability (Cheng et al., 2012), and eventually engendering domination of temperature effects on $\delta^{18} \mathrm{O}$ in precipitation.

Over the last 2000 years, the Kesang $\delta^{18} \mathrm{O}$ record possess distinct centennial-scale variations (Fig. 5 and Fig. 8), whereas multi-decadal and even shorter timescales are insignificant (Fig. 8). This suggests that centennial-scale variations may play a leading role in temperature fluctuations in western China and Central Asia, although water storage in the aquifer and thermal insulation of the host rock probably buffer temperature changes to a certain degree. Following the interpretation outlined above three cold periods can be identified: 800-900 AD, 1200-1300 AD, and 1570-1680 AD (grey bars in Fig. 8), with the last being synchronous with the Little Ice Age. Several warm phases interrupt these cold periods, with a prominent warming trend at the end the record likely reflecting the warming since the 1970s. As shown in Fig. 8, the Kesang reconstruction is in general agreement with ice-core and tree-ring based temperature reconstructions from the central-eastern Tibetan Plateau (Liu et al., 2009; Yao et al., 1996), and correlated with temperature changes in western China (Liu et al., 2013). During the cold period 
from 800-900 AD, the Kesang record differs from the temperature reconstructions in the centraleastern Tibetan Plateau. Lower coverage by tree-ring data and larger uncertainties (Liu et al., 2009) may cause this lack of correspondence during this period.

For the last 1200 years, the Kesang speleothem $\delta^{18} \mathrm{O}$ time series shows similarity to the Guliya ice core $\delta^{18} \mathrm{O}$ record (Yao et al., 1996) and is consistent with the temperature record from the southern Inylchek Glacier from Kyrgyzstan (Aizen, 2008, Fig. 8). This indicates that the larger region of western China, which includes Guliya and our cave sites, might have experienced similar climatic changes; if so, snow accumulation at Guliya can be used to infer the moisture history in western China. The last 1700 years of snow accumulation recorded in the Guliya ice core reveal a significant decrease in precipitation from 400-600 AD. At the same time, $\delta^{18} \mathrm{O}$ in the ice core was enriched for ca. 100 years, indicating a warm and/or dry period around $600 \mathrm{AD}$ (Yao et al., 1996). Increased precipitation (indicated by higher snow accumulation rates) and relatively low temperature intervals reflected in speleothem $\delta^{18} \mathrm{O}_{\mathrm{c}}$ and in the $\delta^{18} \mathrm{O}$ of Guliya ice core during the Little Ice Age strongly suggest a wetter climate. This wetter climate has also been documented recently in the sediments from Lop Nur (Liu et al., 2013) and in geo-biological records from the Tarim Basin (Putnam et al., 2016).

The replicating $\delta^{13} \mathrm{C}$ profiles suggest that $\delta^{13} \mathrm{C}$ is a valid and robust proxy and the $\delta^{13} \mathrm{C}$ variation might be dominated by the climatic change. As shown in Fig. 4, the long-term trend of $\delta^{13} \mathrm{C}$ during the Holocene is decreasing along with many short-term oscillations. The long-term decreasing trend of $\delta^{13} \mathrm{C}$ is opposite to the generally increasing trend of $\delta^{18} \mathrm{O}$ during the Holocene. This is consistent with relationship previously identified in the $500 \mathrm{ka}$ long speleothem record from Kesang Cave (Cheng et al., 2012), in which the $\delta^{13} \mathrm{C}$ values were negatively correlated with the $\delta^{18} \mathrm{O}$ values in general. We also noted much heavier $\delta^{13} \mathrm{C}$ values during some intervals in the Holocene, e.g. $4.2 \mathrm{ka} \mathrm{BP}, 5.3 \mathrm{ka} \mathrm{BP}$ and also the distinct trend to much heavier value since $\sim 1200 \mathrm{AD}(\sim 800 \mathrm{yrs} \mathrm{BP})$. The variation of speleothem calcite $\delta^{13} \mathrm{C}$ could be ascribed to a range of factors that could either be single forcings or act together, namely i) $\mathrm{C} 3 / \mathrm{C} 4$ vegetation composition, ii) vegetation density (biomass), iii) microbial activity in the soil, iv) the contribution of host carbonate rock, v) $\mathrm{CO}_{2}$ degassing processes in the epikarst and/or cave environment from infiltrating water (Breitenbach et al., 2015; Genty et al., 2006; 
Ridley et al., 2015). As the climate was relatively humid during the early and middle Holocene, the long-term decreasing trend may be caused by vegetation-zone shift and/or vegetation composition change above the cave. It is likely that heavier $\delta^{13} \mathrm{C}$ values found in restricted intervals (e.g. around $4 \mathrm{ka} \mathrm{BP}$ ) may be caused by biomass changes and/or prior calcite precipitation processes in response to short-term drying climate. It seems that the long-term trends can be overruled by such short-term excursions, because different forcings are at play, with changing relative importance. However, these interpretations are very preliminary and other independent evidences (e.g. trace element data) are needed to corroborate them.

\subsection{Possible influence of climatic change ca. $500 \mathrm{AD}$ on the abandonment of ancient Loulan} City

The role of climatic and environmental changes in determining the success and failure of societies is still intensely debated (deMenocal, 2001; Donges et al., 2015; Yancheva et al., 2007; Zhang et al., 2005; Zhang et al., 2010). Ascribing all episodes of societal change to climatic events would be too simplistic in Asia, where advanced and complex dynastic societies existed in various climatic and eco-zones (Cunliffe, 2015; Zhang et al., 2010). In arid western China and Central Asia, water availability rather than temperature is the prime climatic determinant for complex human societies. Shifts in moisture distribution across this region possibly had significant impacts on ancient civilizations (Cunliffe, 2015). They in turn likely adapted to the climatic changes by gradually reorganizing systems of supply and production, or abandoning of urban centres (under unfavourable conditions). Placing the archaeological record of cultural change within the context of detailed and well-dated palaeoclimate records presents opportunities to examine how societies responded to climatic change (deMenocal, 2001; Donges et al., 2015).

The famous ancient city of Loulan, located on the western bank of Lake Lop Nor in northeastern Tarim Basin, was the political, economic and cultural centre of western China from c. 77 BC to AD 550 (Xia et al., 2007). Historical documents, and preserved grains of common millet, naked barley and wheat found at the location suggest active agriculture at the time (Wang, 1983). Large-scale reclamation of wasteland around Loulan occurred in the eastern Han dynasty (Zhang, 
2005). An active agricultural practice and a flourishing economy were also documented at two relic sites of Niya and Keria Oasis in southern Tarim Basin as early as 400 AD (Wang et al., 1998). Palaeobotanical evidence reveals that the landscape of ancient Loulan and Milan was a typical oasis prior to desertification and abandonment (Zhang et al., 2013). These lines of evidence suggest a relatively wet climate and sufficient water resources to support societal development at the rim of Tarim Basin.

However, ${ }^{14} \mathrm{C}$ ages of reed remains and wood material found in the ruins, as well as the official literature and archaeological relics suggest that these settlements were populated until 400 AD, and then gradually fell victim to abandonment until 600 AD (Lin, 1991; Wang, 1998). This once prosperous city succumbed to desertification and the region was depopulated by the time the Buddhist monk Xuanzang passed through the area (Niya Oasis) during the Tang dynasty around 644AD (Wang, 1998).

The synchronicity between abandonment around 500 AD and a climate shift to drier conditions (Fig. 8) suggests a significant influence of climate on human habitation, likely due to shortage of sustainable water resources as the root cause (Wang, 1998). Higher temperature and decreased precipitation may have aggravated regional aridity which eventually lead to the abandonment of these settlements at the margin of Tarim Basin. Unfortunately, currently available archaeological data is still too sparse and climate reconstructions need further improvements to draw more specific conclusions about possible links between climatic perturbations and changes in societies in western China.

\section{Conclusions}

A U-series dated high-resolution reconstruction based on multiple stalagmites from Kesang Cave is used to establish a Holocene precipitation $\delta^{18} \mathrm{O}$ time series for Central Asia. Our record indicates low precipitation $\delta^{18} \mathrm{O}$ during the early and middle Holocene, i.e., from 10.0-3.0 ka BP, increased precipitation $\delta^{18} \mathrm{O}$ from 3.0 to $2.0 \mathrm{ka} \mathrm{BP}$, and high values with distinct centennial-scale variations after $2.0 \mathrm{ka} \mathrm{BP}$. 
We explored three potential mechanisms causing the depletion of precipitation $\delta^{18} \mathrm{O}$ during the early and middle Holocene: (i) the penetration of monsoon-related moisture put forward by Cheng et al. (2012); (ii) changes in precipitation seasonality suggested by Kutzbach et al. (2014); and (iii) changes in the isotopic composition of moisture sources proposed in this study. CAM5 model simulations for the preindustrial period and $9 \mathrm{ka} \mathrm{BP}$ appear to rule out changes in precipitation seasonality as a viable explanation. The model results further challenge the hypothesis of increased penetration of monsoonal moisture, as the simulated moisture transport was essentially unchanged in the $9 \mathrm{ka} \mathrm{BP}$ simulation.

We propose that changes in the isotopic composition of moisture coming from surrounding source regions, along with a moistened climate may have contributed to the depletion of $\delta^{18} \mathrm{O}$ in precipitation during the early and middle Holocene. Available records from surrounding regions and also the Ili Basin (the cave site) suggest a generally wetter climate during the early and middle Holocene and corroborate our interpretation.

Our data reveals that the regional climatic regime changed ca. 3.0-2.0 ka BP, with temperature dominating precipitation $\delta^{18} \mathrm{O}$ and a dry climate since then. The inferred temperature changes at the cave site generally agree with the Guliya ice core record and a tree ring-based temperature reconstruction from the Middle Eastern Tibetan Plateau, confirming the large spatial scale temperature change in western China over the last 2000 years.

During the last 2000 years, temperature changes reveal strong centennial-scale oscillations. The combined effects of decreased precipitation and increased temperature ca. 500 AD reduced local water availability and likely contributed to the demise of three settlements at the margin of Tarim Basin, substantiating that the climate changes profoundly affected human society in this area. Detailed comparisons of palaeoclimate and archaeological data are needed to unravel the complexities of human adaptation and response to environmental dynamics.

\section{Acknowledgements}

This work was supported by the Chinese Academy of Sciences (grant XDA05080502, 132B61KYSB20130003), National Natural Science Foundation of China grants (41271229, 
41420104008), and partly supported by the US National Science Foundation (AGS-1405479 to J.C.H. Chiang, and EAR-1211299 to H. Cheng and R. L. Edwards); and funding from the European Union's Horizon 2020 Research and Innovation programme under the Marie Skłodowska-Curie grant agreement No 691037 (to S.F.M. Breitenbach). We thank W. Kong for providing the CAM5 simulations used in this study.

\section{References}

Aizen, V.B., 2008. Is Central Asia really exsiccated? Presentation at the AGU Meeting, December 15-19, 2008, San Francisco, USA.

Aizen, V.B., Aizen, E.M., Melack, J.M., Dozier, J., 1997. Climatic and Hydrologic Changes in the Tien Shan, Central Asia. Journal of Climate 10, 1393-1404.

Aizen, V.B., Aizen, E.M., Joswiak, D.R., Fujita, K., Takeuchi, N., Nikitin, S.A., 2006. Climatic and atmospheric circulation pattern variability from ice-core isotope/geochemistry records (Altai, Tien Shan and Tibet). Annals of Glaciology 43, 49-60.

Almogi-Labin, A., Bar-Matthews, M., Shriki, D., Kolosovsky, E., Paterne, M., Schilman, B., Ayalon, A., Aizenshtat, Z., Matthews, A., 2009. Climatic variability during the last $\sim 90 \mathrm{ka}$ of the southern and northern Levantine Basin as evident from marine records and speleothems. Quaternary Science Reviews 28, 2882-2896.

Bar-Matthews, M., Ayalon, A., Gilmour, M., Matthews, A., Hawkesworth, C.J., 2003. Sea-land oxygen isotopic relationships from planktonic foraminifera and speleothems in the Eastern Mediterranean region and their implication for paleorainfall during interglacial intervals. Geochimica et Cosmochimica Acta 67, 3181-3199.

Bar-Matthews, M., Ayalon, A., Kaufman, A., 1997. Late Quaternary Paleoclimate in the Eastern Mediterranean Region from Stable Isotope Analysis of Speleothems at Soreq Cave, Israel. Quaternary Research 47, 155-168.

Battisti, D., Ding, Q., Roe, G., 2014. Coherent pan - Asian climatic and isotopic response to orbital forcing of tropical insolation. Journal of Geophysical Research: Atmospheres 119.

Bollasina, M.A., Ming, Y., Ramaswamy, V., 2011. Anthropogenic aerosols and the weakening of the South Asian summer monsoon. Science 334, 502-505.

Breitenbach, S.F.M., Adkins, J.F., Meyer, H., Marwan, N., Kumar, K.K., Haug, G.H., 2010. Strong influence of water vapor source dynamics on stable isotopes in precipitation observed in Southern Meghalaya, NE India. Earth and Planetary Science Letters 292, 212-220. 
Breitenbach S.F.M., Lechleitner F.A., Meyer H., Diengdoh G., Mattey D., Marwan N. (2015) Cave ventilation and rainfall signals in dripwater in a monsoonal setting - a monitoring study from NE India. Chemical Geology 402, 111-124.

Breitenbach, S.F.M., Rehfeld, K., Goswami, B., Baldini, J.U.L., 2012. COnstructing Proxy Records from Age models (COPRA). Climate of the Past 8, 1765-1779.

Cai, Y., Cheng, H., An, Z., Edwards, R.L., Wang, X., Tan, L., Wang, J., 2010. Large variations of oxygen isotopes in precipitation over south-central Tibet during Marine Isotope Stage 5. Geology 38, 243-246.

Cai, Y., Fung, I.Y., Edwards, R.L., An, Z., Cheng, H., Lee, J.-E., Tan, L., Shen, C.-C., Wang, X., Day, J.A., 2015. Variability of stalagmite-inferred Indian monsoon precipitation over the past 252,000 y. Proceedings of the National Academy of Sciences 112, 2954-2959.

Cai, Y., Zhang, H., Cheng, H., An, Z., Lawrence Edwards, R., Wang, X., Tan, L., Liang, F., Wang, J., Kelly, M., 2012. The Holocene Indian monsoon variability over the southern Tibetan Plateau and its teleconnections. Earth and Planetary Science Letters 335-336, 135-144.

Chen, F., Yu, Z., Yang, M., Ito, E., Wang, S., Madsen, D.B., Huang, X., Zhao, Y., Sato, T., John B. Birks, H., Boomer, I., Chen, J., An, C., Wünnemann, B., 2008. Holocene moisture evolution in arid central Asia and its out-of-phase relationship with Asian monsoon history. Quaternary Science Reviews 27, 351-364.

Cheng, H., Lawrence Edwards, R., Shen, C.-C., Polyak, V.J., Asmerom, Y., Woodhead, J., Hellstrom, J., Wang, Y., Kong, X., Spötl, C., Wang, X., Calvin Alexander Jr, E., 2013. Improvements in ${ }^{230} \mathrm{Th}$ dating, ${ }^{230} \mathrm{Th}$ and ${ }^{234} \mathrm{U}$ half-life values, and $\mathrm{U}-\mathrm{Th}$ isotopic measurements by multi-collector inductively coupled plasma mass spectrometry. Earth and Planetary Science Letters 371-372, 82-91.

Cheng, H., Sinha, A., Verheyden, S., Nader, F., Li, X., Zhang, P., Yin, J., Yi, L., Peng, Y., Rao, Z., 2015. The climate variability in northern Levant over the past 20,000 years. Geophysical Research Letters 42, 8641-8650.

Cheng, H., Zhang, P.Z., Spötl, C., Edwards, R.L., Cai, Y.J., Zhang, D.Z., Sang, W.C., Tan, M., An, Z.S., 2012. The climatic cyclicity in semiarid-arid central Asia over the past 500,000 years. Geophysical Research Letters 39, L01705.

Chiang, J.C.H., Fung, I.Y., Wu, C.-H., Cai, Y., Edman, J.P., Liu, Y., Day, J.A., Bhattacharya, T., Mondal, Y., Labrousse, C.A., 2015. Role of seasonal transitions and westerly jets in East Asian paleoclimate. Quaternary Science Reviews 108, 111-129.

Cunliffe B. (2015) By Steppe, Desert, and Ocean. The Birth of Eurasia. Oxford University Press. 530 pages.

Dansgaard, W., 1964. Stable isotopes in precipitation. Tellus 16, 436-468. 
deMenocal, P.B., 2001. Cultural Responses to Climate Change During the Late Holocene. Science 292, 667-673.

Donges, J.F., Donner, R., Marwan, N., Breitenbach, S.F., Rehfeld, K., Kurths, J., 2015. Nonlinear regime shifts in Holocene Asian monsoon variability: potential impacts on cultural change and migratory patterns. Climate of the Past 11, 709-741.

Dorale, J.A., Edwards, R.L., Ito, E., Gonzalez, L.A., 1998. Climate and Vegetation History of the Midcontinent from 75 to $25 \mathrm{ka}$ : A Speleothem Record from Crevice Cave, Missouri, USA. Science 282, 1871-1874.

Dorale, J.A. and Liu, Z., 2009. Limitations of Hendy test criteria in judging the paleoclimatic suitability of speleothems and the need for replication. Journal of Cave and Karst Studies 71, 7380.

Edwards, R.L., Chen, J.H., Wasserburg, G.J., 1987. ${ }^{238} \mathrm{U}-{ }^{234} \mathrm{U}^{230}{ }^{23} \mathrm{Th}^{232} \mathrm{Th}$ systematic and the precise measurement of time over the past 500,000 years. Earth and Planetary Science Letters 81, 175-192.

Fang X.Q, Hou, G.L 2011. Synthetically Reconstructed Holocene Temperature Change in China. Scientia Geographica Sinica, 31, 385-393. In Chinese with English abstract.

Fleitmann, D., Burns, S.J., Mangini, A., Mudelsee, M., Kramers, J., Villa, I., Neff, U., AlSubbary, A.A., Buettner, A., Hippler, D., Matter, A., 2007. Holocene ITCZ and Indian monsoon dynamics recorded in stalagmites from Oman and Yemen (Socotra). Quaternary Science Reviews 26, 170-188.

Genty, D., Blamart, D., Ghaleb, B., Plagnes, V., Causse, C., Bakalowicz, M., Zouari, K., Chkir, N., Hellstrom, J., Wainer, K., Bourges, F., 2006. Timing and dynamics of the last deglaciation from European and North African $\delta^{13} \mathrm{C}$ stalagmite profiles - comparison with Chinese and South Hemisphere stalagmites. Quaternary Science Reviews 25, 2118-2142.

Han, S.T., Qu, Z., 1992. Holocene inland environmental change sequence of Barkol Lake, North Xinjiang. Science in China Series B 11, 1201-1209 (in Chinese).

Hendy, C.H., 1971. The isotopic geochemistry of speleothems-I. The calculation of the effects of different modes of formation on the isotopic composition of speleothems and their applicability as palaeoclimatic indicators. Geochimica et Cosmochimica Acta 35, 801-824. Herzschuh, U., 2006. Palaeo-moisture evolution in monsoonal Central Asia during the last 50,000 years. Quaternary Science Reviews 25, 163-178.

Huang, X.Z., Chen, F.H., Fan, Y.X., Yang, M.L., 2009. Dry late-glacial and early Holocene climate in arid central Asia indicated by lithological and palynological evidence from Bosten Lake, China. Quaternary International 194, 19-27. 
Hurrell, J., Holland, M., Gent, P., Ghan, S., Kay, J., Kushner, P., Lamarque, J., Large, W., Lawrence, D., Lindsay, K., 2013. The community earth system model: a framework for collaborative research, B. Am. Meteorol. Soc., 94, 1339-1360, doi: 10.1175. BAMS-D-1200121.1.

Jiang, Q., Ji, J., Shen, J., Matsumoto, R., Tong, G., Qian, P., Ren, X., Yan, D., 2013. Holocene vegetational and climatic variation in westerly-dominated areas of Central Asia inferred from the Sayram Lake in northern Xinjiang, China. Sci. China Earth Sci. 56, 339-353.

Jiang, Q.F., Shen, J., Liu, X.Q., Zhang, E.L., 2007. Holocene climate reconstruction of Wulungu Lake (Xinjiang, China) inferred from ostracod species assemblages and stable isotopes.

Quaternary Research 27, 382-391 (in Chinese with English abstract).

Johnson, K.R., Ingram, B.L., 2004. Spatial and temporal variability in the stable isotope systematics of modern precipitation in China: implications for paleoclimate reconstructions. Earth and Planetary Science Letters 220, 365-377.

Kalnay, E., Kanamitsu, M., Kistler, R., Collins, W., Deaven, D., Gandin, L., Iredell, M., Saha, S., White, G., Woollen, J., Zhu, Y., Chelliah, M., Ebisuzaki, W., Higgins, W., Janowiak, J., Mo, K.C., Ropelewski, C., Wang, J., Leetmaa, A., Reynolds, R., Jenne, R., Joseph, D., 1996. The NCEP/NCAR 40-year reanalysis project. Bulletin of the American Meteorological Society 77, 437-471.

Kaser, G., Grosshauser, M., Marzeion, B., 2010. Contribution potential of glaciers to water availability in different climate regimes. P Natl Acad Sci USA 107, 20223-20227.

Kim, S.-T., O'Neil, J.R., 1997. Equilibrium and nonequilibrium oxygen isotope effects in synthetic carbonates. Geochimica et Cosmochimica Acta 61, 3461-3475.

Kistler, R., Kalnay, E., Collins, W., Saha, S., White, G., Woollen, J., Chelliah, M., Ebisuzaki, W., Kanamitsu, M., Kousky, V., van den Dool, H., Jenne, R., Fiorino, M., 2001. The NCEPNCAR 50-year reanalysis: monthly means CD-ROM and documentation. Bull. Am. Meteorol. Soc. 82, 247-267.

Kolodny, Y., Stein, M., Machlus, M., 2005. Sea-rain-lake relation in the Last Glacial East Mediterranean revealed by $\delta^{18} \mathrm{O}-\delta^{13} \mathrm{C}$ in Lake Lisan aragonites. Geochimica et Cosmochimica Acta 69, 4045-4060.

Kong, W.W., Swenson, L.M., Chiang, J.C.H., 2016. Seasonal Transitions and the Westerly Jet in the Holocene East Asian Summer Monsoon. Journal of Climate, under review.

Kutzbach, J.E., Chen, G., Cheng, H., Edwards, R.L., Liu, Z., 2014. Potential role of winter rainfall in explaining increased moisture in the Mediterranean and Middle East during periods of maximum orbitally-forced insolation seasonality. Climate Dynamics 42, 1079-1095. 
Lee, J.-E. and Fung, I., 2008. "Amount effect" of water isotopes and quantitative analysis of post-condensation processes. Hydrological Processes 22, 1-8.

Lee, J.-E., Risi, C., Fung, I., Worden, J., Scheepmaker, R.A., Lintner, B., Frankenberg, C., 2012. Asian monsoon hydrometeorology from TES and SCIAMACHY water vapor isotope measurements and LMDZ simulations: Implications for speleothem climate record interpretation. Journal of Geophysical Research: Atmospheres 117.

Li, X., Zhao, K., Dodson, J., Zhou, X., 2011. Moisture dynamics in central Asia for the last 15 kyr: new evidence from Yili Valley, Xinjiang, NW China. Quaternary Science Reviews 30, 3457-3466.

Lin, M.C., 1991. A study on the lineage of the Shanshan Dynasty during the Kharoshi period. The Western Regions Studies 1, 39-50. (in Chinese)

Liu, W., Liu, Z., An, Z., Wang, X., Chang, H., 2011. Wet climate during the 'Little Ice Age' in the arid Tarim Basin, northwestern China. The Holocene 21, 409-416.

Liu, X., Herzschuh, U., Shen, J., Jiang, Q., Xiao, X., 2008. Holocene environmental and climatic changes inferred from Wulungu Lake in northern Xinjiang, China. Quaternary Research 70, 412425 .

Liu, Y., An, Z., Linderholm, H.W., Chen, D., Song, H., Cai, Q., Sun, J., Tian, H., 2009. Annual temperatures during the last 2485 years in the mid-eastern Tibetan Plateau inferred from tree rings. Science in China Series D: Earth Sciences 52, 348-359.

Liu, Y., Cai, Q.F., Song, H.M., 2013, Seasonal and spatial representativeness of the tree-ring based 2485-year annual mean temperature reconstruction in the northeastern Tibetan Plateau. Quaternary Sciences 33 (1), 108-114. (in Chinese with English abstract)

Mischke, S. and Wünnemann, B., 2006. The Holocene salinity history of Bosten Lake (Xinjiang, China) inferred from ostracod species assemblages and shell chemistry: Possible palaeoclimatic implications. Quaternary International 154-155, 100-112.

Narisma, G.T., Foley, J.A., Licker, R., Ramankutty, N., 2007. Abrupt changes in rainfall during the twentieth century. Geophysical Research Letters 34, 1-5.

Porter, S.C., An, Z.S., 1995. Correlation between climate events in the North Atlantic and China during the last glaciation. Nature 375, 185-188.

Putnam, A.E., Putnam, D.E., Andreu-Hayles, L., Cook, E.R., Palmer, J.G., Clark, E.H., Wang, C., Chen, F., Denton, G.H., Boyle, D.P., 2016. Little Ice Age wetting of interior Asian deserts and the rise of the Mongol Empire. Quaternary Science Reviews 131, 33-50.

Qin, D.H., Chen, Y.Y., Li, X.Y., 2005. Assessment of Climate and Environment Changes in China, vol. 1: Climate and Environment Changes in China and their Projection. Chinese Science Press, Beijing (in Chinese). 
Ran, M., Feng, Z., 2013. Holocene moisture variations across China and driving mechanisms: A synthesis of climatic records. Quaternary International 313, 179-193.

Rasmussen, K.A., Ricketts, R.D., Johnson, T.C., Romanovsky, V.V., Grigina, O.M., 2001. An 8,000 year multi-proxy record from Lake Issyk-Kul, Kyrgyzstan. PAGES News 9, 5-6.

Ricketts, R., Johnson, T., Brown, E., Rasmussen, K., Romanovsky, V., 2001. The Holocene paleolimnology of Lake Issyk-Kul, Kyrgyzstan: Trace element and stable isotope composition of ostracodes. Palaeogeography, Palaeoclimatology, Palaeoecology 176, 207-227.

Ridley, H., Asmerom, Y., Baldini, J.U.L., Breitenbach, S.F.M., Aquino, V.V., Prufer, K.M., Culleton, B.J., Polyak, V.J., Lechleitne,r F.A., Kennett, D.J., Zhang, M., Marwan, N., Macpherson, C.G., Baldini, L.M., Xiao, T., Awe, J., Haug, G.H., 2015. Aerosol forcing of the position of the intertropical convergence zone since AD 1550. Nature Geoscience 8, 195-200.

Risi, C., Bony, S., Vimeux, F., 2008. Influence of convective processes on the isotopic composition $\left(\delta^{18} \mathrm{O}\right.$ and $\left.\delta \mathrm{D}\right)$ of precipitation and water vapor in the tropics: 2. Physical interpretation of the amount effect. Journal of Geophysical Research 113, D19306, doi:19310.11029/12008JD009943.

Rudaya, N., Tarasov, P., Dorofeyuk, N., Solovieva, N., Kalugin, I., Andreev, A., Daryin, A., Diekmann, B., Riedel, F., Tserendash, N., Wagner, M., 2009. Holocene environments and climate in the Mongolian Altai reconstructed from the Hoton-Nur pollen and diatom records: a step towards better understanding climate dynamics in Central Asia. Quaternary Science Reviews 28, 540-554.

Schiemann, R., Lüthi, D., Vidale, P.L., Schär, C., 2008. The precipitation climate of Central Asia-intercomparison of observational and numerical data sources in a remote semiarid region. International Journal of Climatology 28, 295-314.

Sorg, A., Bolch, T., Stoffel, M., Solomina, O., Beniston, M., 2012. Climate change impacts on glaciers and runoff in Tien Shan (Central Asia). Nature Climate Change 2, 725-731.

Sun, X.J., Du, N.Q., Weng, C.Y., Lin, R.F., Wei, K.Q., 1994. Paleovegetation and paleoenvironment of Manasi Lake, Xinjiang, N.W. China during the last 14000 years. Quaternary Sciences 14, 239-248.

Sun, Y., Clemens, S.C., Morrill, C., Lin, X., Wang, X., An, Z., 2012. Influence of Atlantic meridional overturning circulation on the East Asian winter monsoon. Nature Geoscience 5, 4649.

Thompson, L.G., Mosley-Thompson, E., Davis, M.E., Bolzan, J.F., Dai, J., Yao, T., Gundestrup, N., Wu, X., Klein, L., Xie, Z., 1989. Holocene late Pleistocene climatic ice core records from Qinghai-Tibetan Plateau. Science 246, 474-477. 
Thompson, L.G., Yao, T., Davis, M.E., Henderson, K.A., Mosley-Thompson, E., Lin, P.-N., Beer, J., Synal, H.-A., Cole-Dai, J., Bolzan, J.F., 1997. Tropical climate instability: the last glacial cycle from a Qinghai-Tibetan ice core. Science 276, 1821-1825.

Torfstein, A., Haase-Schramm, A., Waldmann, N., Kolodny, Y., Stein, M., 2009. U-series and oxygen isotope chronology of the mid-Pleistocene Lake Amora (Dead Sea basin): Geochimica et Cosmochimica Acta 73, 2603-2630.

Tzedakis, P.C., 2007. Seven ambiguities in the Mediterranean palaeoenvironmental narrative. Quaternary Science Reviews 26, 2042-2066.

Waldmann, N., Torfstein, A., Stein, M., 2010. Northward intrusions of low- and mid-latitude storms across the Saharo-Arabian belt during past interglacials. Geology 38, 567-570.

Wang, B.H., 1983. An overview on the agricultural archaeology in Xinjiang, Agricultural Archaeology 1, 102-117. (in Chinese)

Wang, S., 1998. The abandonment of three major ancient ruins groups and environmental change in Tarim Basin. Quaternary Sciences 2, 71-79. (in Chinese with English abstract)

Wang, S., Gong, D., Zhu, J., 2001b. Twentieth-century climatic warming in China in the context of the Holocene. The Holocene 11, 313-321.

Wang, W., Feng, Z., Ran, M., Zhang, C., 2013. Holocene climate and vegetation changes inferred from pollen records of Lake Aibi, northern Xinjiang, China: A potential contribution to understanding of Holocene climate pattern in East-central Asia. Quaternary International 311, 54-62.

Wang, Y.J., Cheng, H., Edwards, R.L., An, Z.S., Wu, J.Y., Shen, C.-C., Dorale, J.A., 2001a. A high-resolution absolute-dated late Pleistocene Monsoon record from Hulu cave, China. Science 294, 2345-2348.

Winkler, M.G. and P.K. Wang (1993). The Late-Quaternary vegetation and climate of China, in Global Climates since the Last Glacial Maximum, edited by H. E. Wright Jr. et al., chap. 10, 221-264, Univ. of Minn. Press, Minneapolis.

Wolff, C., Plessen, B., Dudashvili, A., Breitenbach, S. F. M., Cheng, H., Edwards, L., Strecker, M., 2016. Precipitation evolution of Central Asia during the last 5000 years. The Holocene, doi: $10.1177 / 0959683616652711,1-13$.

Wünnemann, B., Mischke, S., Chen, F., 2006. A Holocene sedimentary record from Bosten Lake, China. Palaeogeography, Palaeoclimatology, Palaeoecology 234, 223-238.

Xia, X.C., Wang, B.F., Zhao, Y.J., 2007. Lop Nor in China. Beijing: Science Press (in Chinese). 
Yancheva, G., Nowaczyk, N.R., Mingram, J., Dulski, P., Schettler, G., Negendank, J.F.W., Liu, J., Sigman, D.M., Peterson, L.C., Haug, G.H., 2007. Influence of the intertropical convergence zone on the East Asian monsoon. Nature 445, 74-77.

Yao, T., Thompson, L.G., Qin, D., Tian, L., Jiao, K., Yang, Z., Xie, C., (1996), Variations in temperature and precipitation in the past 2000 a on the Xizang (Tibet) Plateau-Guliya ice core record, Sci. China Ser. D 39, 425-433.

Zhang, D., 2005. Historical records of environmental changes and agriculture development in northwest China. Advances in Climate Change Research. 1(2): 58-64. (in Chinese with English abstract)

Zhang, D., Jim, C., Lin, C., He, Y., Lee, F., 2005. Climate change, social unrest and dynastic transition in ancient China. Chinese Science Bulletin 50, 137-144.

Zhang, D., Li, H.-C., Ku, T.-L., Lu, L., 2010. On linking climate to Chinese dynastic change: Spatial and temporal variations of monsoonal rain. Chinese Science Bulletin 55, 77-83.

Zhang, J., Lu, H., Wu, N., Qin, X., Wang, L., 2013. Palaeoenvironment and agriculture of ancient Loulan and Milan on the Silk Road. The Holocene 23, 208-217.

Zhang, X.Y., Arimoto, R., An, Z.S., 1997. Dust emission from Chinese desert sources linked to variation in atmospheric circulation. Journal of Geophysical Research-Atmospheres 102, 2804128047.

Zhao, H., Li, S.-H., Li, B., Li, G.-Q., 2015. Holocene climate changes in westerly-dominated areas of central Asia: Evidence from optical dating of two loess sections in Tianshan Mountain, China. Quaternary Geochronology 30, Part B, 188-193.

Zhao, Y., Huang, A., Zhou, Y., Huang, D., Yang, Q., Ma, Y., Li, M., Wei, G., 2014b. Impact of the Middle and Upper Tropospheric Cooling over Central Asia on the Summer Rainfall in the Tarim Basin, China. Journal of Climate 27, 4721-4732.

Zhao, Y., Wang, M., Huang, A., Li, H., Huo, W., Yang, Q., 2014a. Relationships between the West Asian subtropical westerly jet and summer precipitation in northern Xinjiang. Theoretical and Applied Climatology 116, 403-411.

Zhong, W., Xue, J.B., Li, X.D., Xu, H.J., Jun, O.Y., 2010. A Holocene climate denoted by geochemical from Barkol Lake in the northeastern Xinjiang, NW China. Geochemistry International 48, 792-800. 


\section{Captions}

Fig. 1. a) Location of different records in topographic map. GTOPO30 data distributed by U.S. Geological Survey's EROS (Earth Resources Observation and Science;

http://eros.usgs.gov/\#/Find_Data/Products_and_Data_Available/gtopo30_info) Data Center were used to plot topographic map. Averaged wind field at $850 \mathrm{hPa}$ isobaric in summer (white arrow) and winter (red arrow) from 1981 to 2010 (NCEP Reanalysis Derived data provided by the NOAA/OAR/ESRL PSD, Boulder, Colorado, USA, from their Web site at http://www.esrl.noaa.gov/psd/ ). b) Mean annual precipitation (mm) in the study region from 1951 to 2007 . c) The mean ratio of the winter half year (January to April, November and December) precipitation to annual precipitation in the study region from 1951 to 2007. Precipitation seasonality shifts from west (dominated by winter precipitation) to east (dominated by summer precipitation). The location of Kesang Cave (as well as the Yili Basin) is denoted by red star (N42 52', E81 45', 2070m a.b.s.1.), all other records are denoted by pink circles: G, Guliya Ice core, N35¹7’, E81²9’, 6200m a.b.s.l.; I, Issyk-Kul Lake, N42³0', E77º6’, 1605m a.b.s.1.; S, Sayram Lake, N44³6', E81 ${ }^{\circ} 12^{\prime}$, 2075m a.b.s.1.; M, Manas Lake, N4548', E86 ${ }^{\circ} 00^{\prime}, ~ 255 \mathrm{~m}$ a.b.s.1.; B, Boston Lake, N42 ${ }^{\circ} 00^{\prime}, \mathrm{E} 87^{\circ} 01^{\prime}, \sim 1050 \mathrm{~m}$ a.b.s.1.. The location of ancient cities are denoted by white squares, 1, Loulan, $\mathrm{N}^{\circ} 0^{\circ} 31^{\prime}$, E89 $55^{\circ}$, , 780m a.b.s.1.; 2,

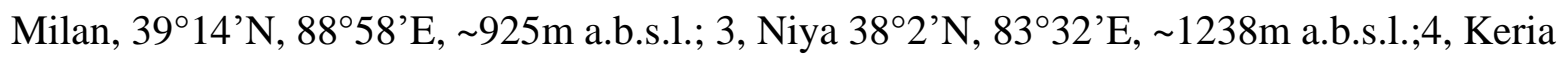
$37^{\circ} 22^{\prime} \mathrm{N}, 7^{\circ} 51^{\prime} \mathrm{E}, \sim 1301 \mathrm{~m}$ a.b.s.1..

Fig. 2. The cross sections of stalagmites CNKS-2, CNKS-3, CNKS-7 and CNKS-9 cut along the growth axis showing bands of growth layers. ${ }^{230}$ Th dates are also indicated beside the drilling position.

Fig. 3. Plots of the age versus depth for stalagmite CNKS-2, CNKS-3, CNKS-7 and CNKS-9. All ages of the stalagmites are reported as thousand years before the present (1950), ka BP. The age errors indicated in the plots are $2 \sigma$ error. The modeling program COPRA (Breitenbach et al., 2012) is used to calculate the chronologies of all these stalagmites. The red dashed line indicates the confidence level of $95 \%$. In panels of CNKS-2 and CNKS-3, the gray lines show the tuned 
chronology we used in the following plots (see the text for details), while the black lines show the COPRA output calculated with U-series dates.

Fig. 4. The time series of speleothem $\delta^{13} \mathrm{C}$ obtained from Kesang Cave. The red dashed lines and blue solid lines denote different stalagmites in each panel. Replications in $\delta^{13} \mathrm{C}$ during the overlapped periods further confirm these stalagmites are most likely deposited under the isotopic equilibrium conditions and that the variations of $\delta^{18} \mathrm{O}_{\mathrm{c}}$ are dominated by climate variations, i.e., changes in the oxygen isotopic composition of meteoric precipitation and cave temperature at the time of calcite precipitation.

Fig. 5. (A) Comparison of oxygen isotopic records from stalagmites CNKS-7 (red), CNKS-9 (blue) and those reported in Cheng et al. (2012) from Kesang Cave (dark gray), western China with the $\delta^{18} \mathrm{O}$ records from Dongge Cave (dark green, Wang et al., 2005), southern China, Peqiin Cave, northern Israel (violet, Bar-Matthews, 2003) and Jeita Cave, Lebanon (light green, Cheng et al., 2015). The horizontal pink lines above the Kesang time series indicate the mean $\delta^{18} \mathrm{O}$ values of $-10.4 \%$ and $-8.3 \%$ during the periods of 10.7-3.0 ka BP (light green shaded) and after $2.0 \mathrm{ka}$ BP (light yellow shaded), respectively. The dashed line indicates the value of $-9.7 \%$, which demarcates the shift from mainly lower than most $\delta^{18} \mathrm{O}$ values in the early period (10.73.0 ka BP) to higher values the later period (after $2.0 \mathrm{ka} \mathrm{BP}$ ) (B) Reconstructed moisture changes at different sites in central Asia based on lake sediments, i.e., Lake Issyk-Kul, Ricketts et al., 2001; Yili Basin, Li et al., 2011; Sayram Lake, Jiang et al., 2013; Manas Lake, Sun et al., 1994; Boston Lake, Wünnemann et al., 2006. The different gray-shaded bars indicate reconstructed climatic conditions, i.e., from black to light gray illustrating wetter to relatively drier conditions.

Fig. 6. (a) Hovmoller diagram of precipitation seasonality over central Asian as simulated in the CAM5 preindustrial simulation. It shows rainfall (contour interval $0.5 \mathrm{~mm} / \mathrm{d}$ ) of climatological rainfall at $42.9^{\circ} \mathrm{N}$, which is the latitude of Kesang Cave. The wintertime-dominated precipitation seasonality is clearly seen to the west of $\sim 73^{\circ} \mathrm{E}$, and the summertime-dominated seasonality to the east of $\sim 73^{\circ} \mathrm{E}$. The dashed line is the approximate longitude of Kesang Cave. 
(b) Monthly mean rainfall climatology at the gridpoint closest to Kesang Cave $\left(81.75^{\circ} \mathrm{E}, 42.9^{\circ} \mathrm{N}\right)$ for the preindustrial simulation (solid line) and the 9ka simulation (dashed line). 9ka rainfall $(\mathrm{mm} / \mathrm{d})$ is slightly weaker during the spring, and slightly increased in the summer, compared to the preindustrial.

Fig. 7. (a) Difference in the June-August specific humidity over the Tibetan Plateau and Tarim basin, $9 \mathrm{ka}$ minus preindustrial. The data is averaged over $80^{\circ} \mathrm{E}-83^{\circ} \mathrm{E}$, encompassing the longitude of Kesang Cave. Contour interval $0.2 \mathrm{~g} / \mathrm{kg}$. $\quad$ (b) Zonal moisture transport (UQ) for the 9ka simulation averaged over $41^{\circ} \mathrm{N}$ to $44^{\circ} \mathrm{N}$, encompassing the Kesang latitude. (c) Meridional moisture transport (VQ) for the $9 \mathrm{ka}$ simulation averaged over $40^{\circ} \mathrm{N}$ to $42^{\circ} \mathrm{N}$, just south of Kesang Cave. For (b) and (c), the contour interval is $5(\mathrm{~m} / \mathrm{s})(\mathrm{g} / \mathrm{kg})$ and positive values imply eastward or northward transport. In all panels, the black dashed line indicates the approximate location of Kesang Cave.

Fig. 8. Comparisons of the Kesang stalagmite $\delta^{18} \mathrm{O}$ records (b: red, CNKS-3; blue, CNKS-2; grey, CNKS-9) with the $\delta^{18} \mathrm{O}$ (c: brown) and accumulation (d: purple) records of Guliya Ice core (Yao et al., 1996), and the tree ring record (a: light blue) from the central-eastern Tibetan Plateau (Liu et al., 2009). The ice core reconstructed temperature changes (c: green) at the Tien Shan southern Inylchek Glacier, Kyrgyzstan (Aizen, 2008), were also present along with the Guliya ice core $\delta^{18} \mathrm{O}$ record. The two dark blue lines in (a) and (c) are also the Kesang $\delta^{18} \mathrm{O}$ records of CNKS-2 and CNKS-3. 
Table 1. ${ }^{230}$ Th dating results. The error is $2 \sigma$ error.

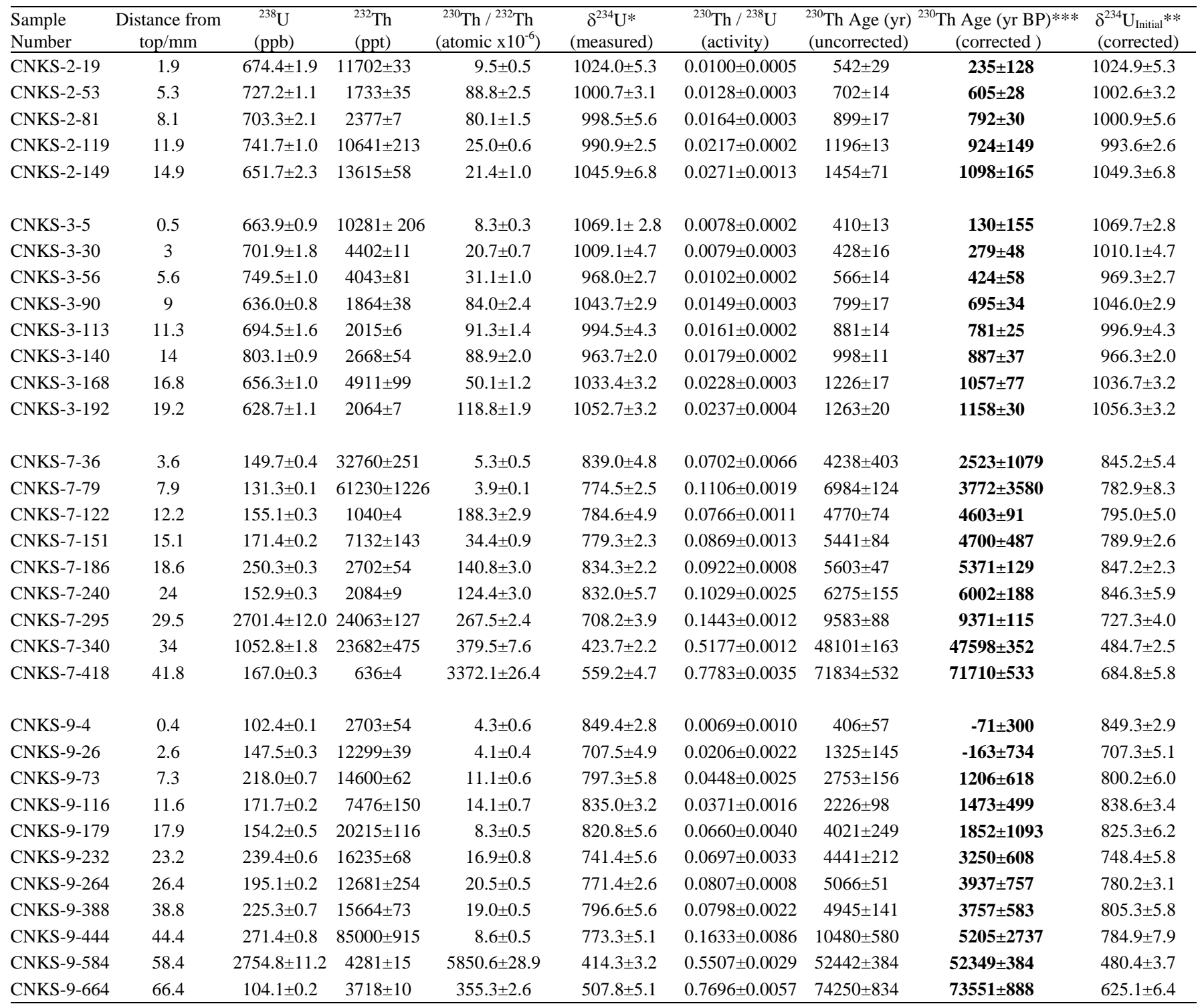

$* \delta^{234} \mathrm{U}=\left(\left[{ }^{234} \mathrm{U} /{ }^{238} \mathrm{U}\right]_{\text {activity }}-1\right) \times 1000 . * * \delta^{234} \mathrm{U}_{\text {initial }}$ was calculated based on ${ }^{230} \mathrm{Th}$ age $(\mathrm{T})$, i.e., $\delta^{234} U_{\text {initial }}=$ $\delta^{234} U_{\text {measured }} \times e^{\lambda 234 \times T}$. Corrected ${ }^{230} \mathrm{Th}$ ages assume the initial ${ }^{230} \mathrm{Th} /{ }^{232} \mathrm{Th}$ atomic ratio of $4.4 \pm 2.2 \times 10^{-6}$ (the value used by Cheng et al., 2012). Those are the values for a material at secular equilibrium, with the bulk earth ${ }^{232} \mathrm{Th} /{ }^{238} \mathrm{U}$ value of 3.8 . The errors are arbitrarily assumed to be $50 \%$. ***B.P. stands for "Before Present" where the "Present" is defined as the year 1950 A.D. 


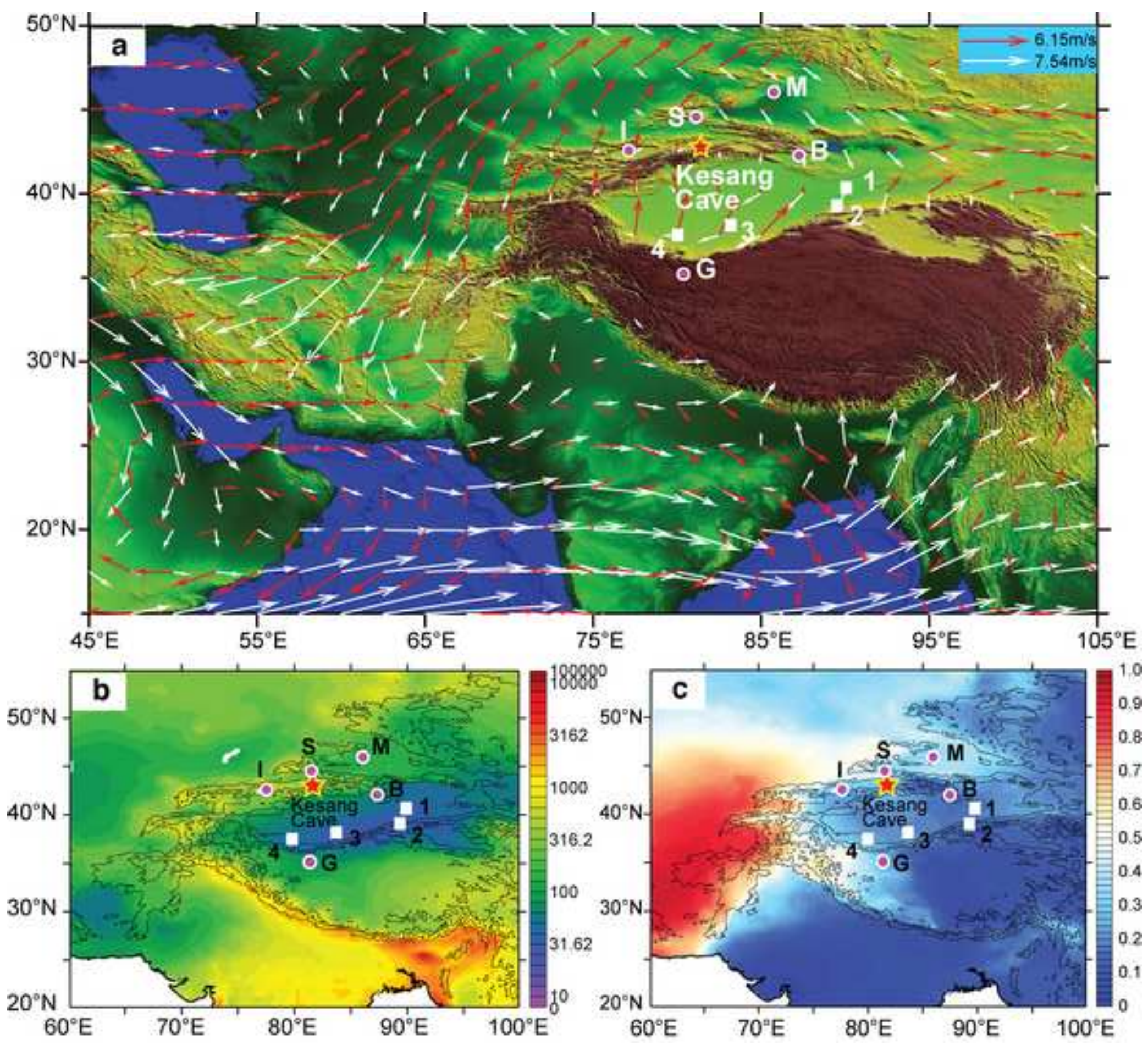



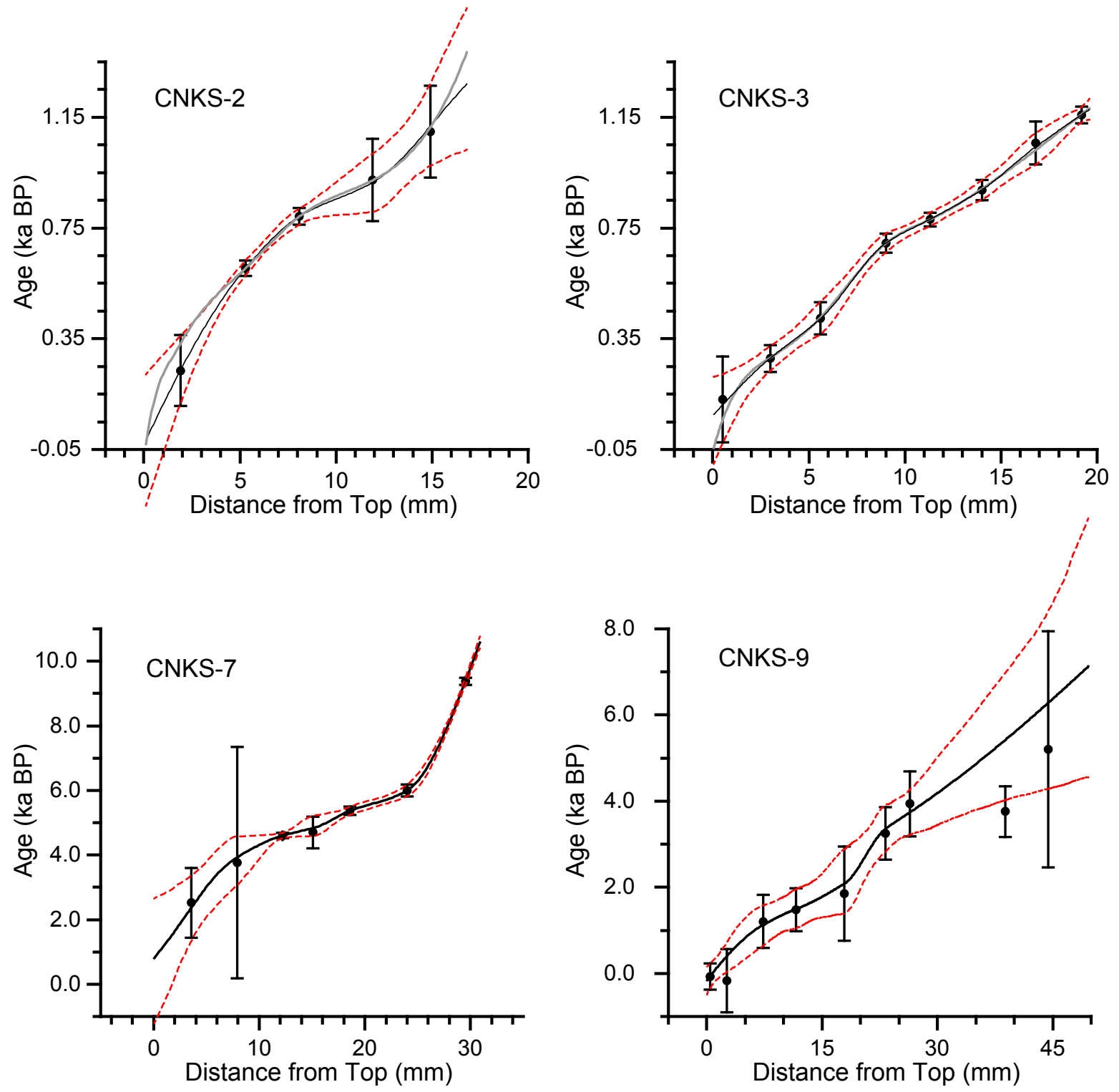

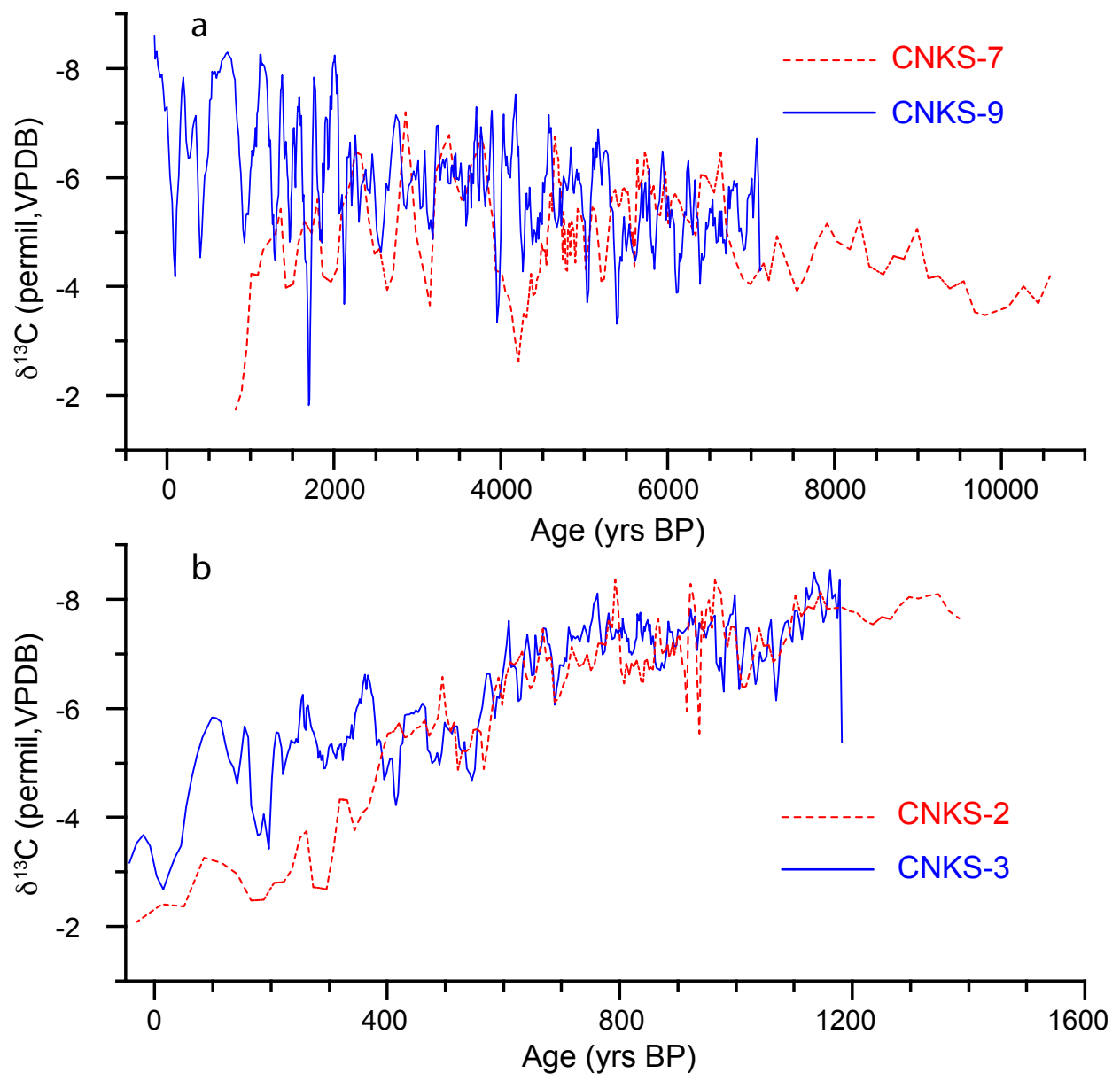


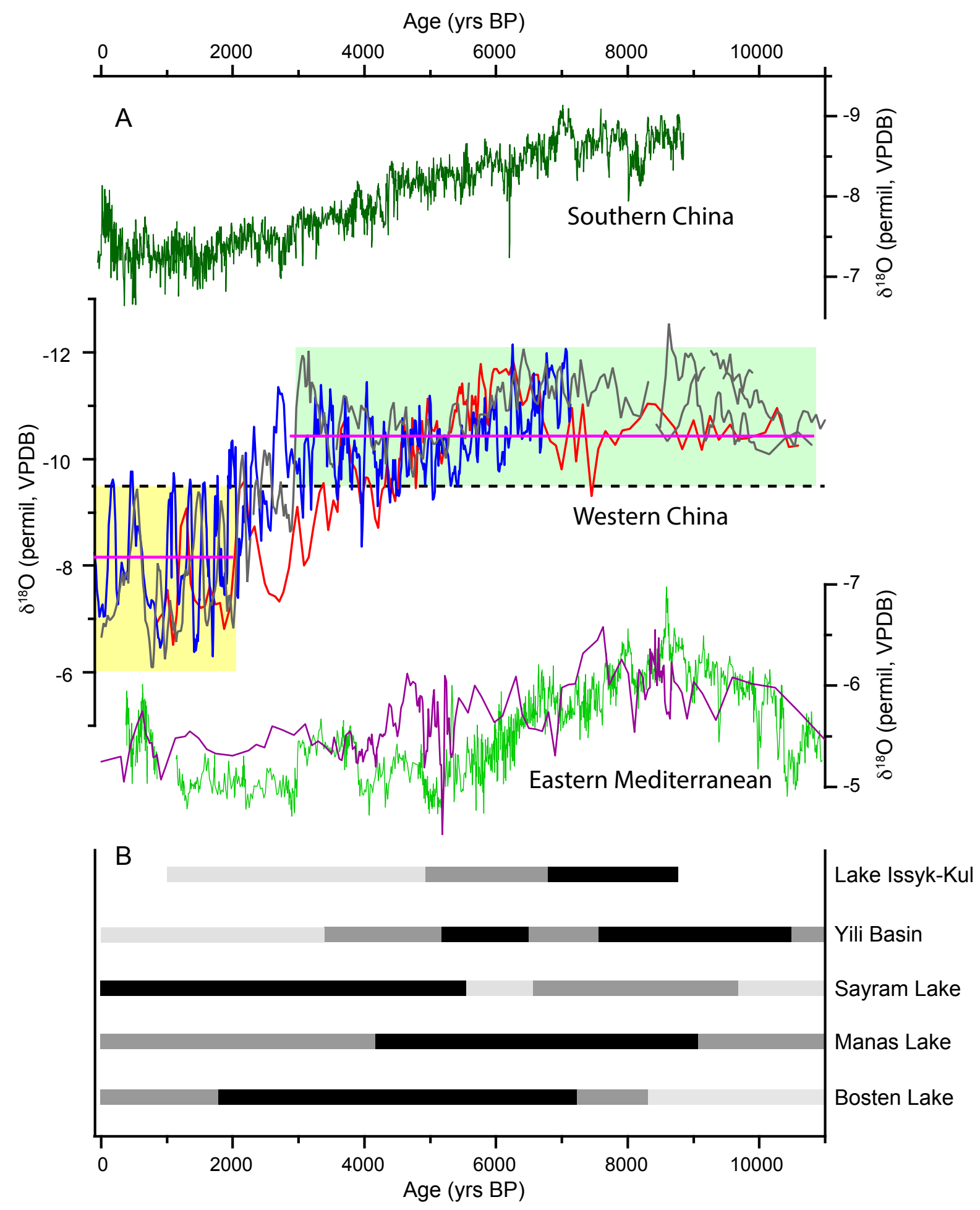



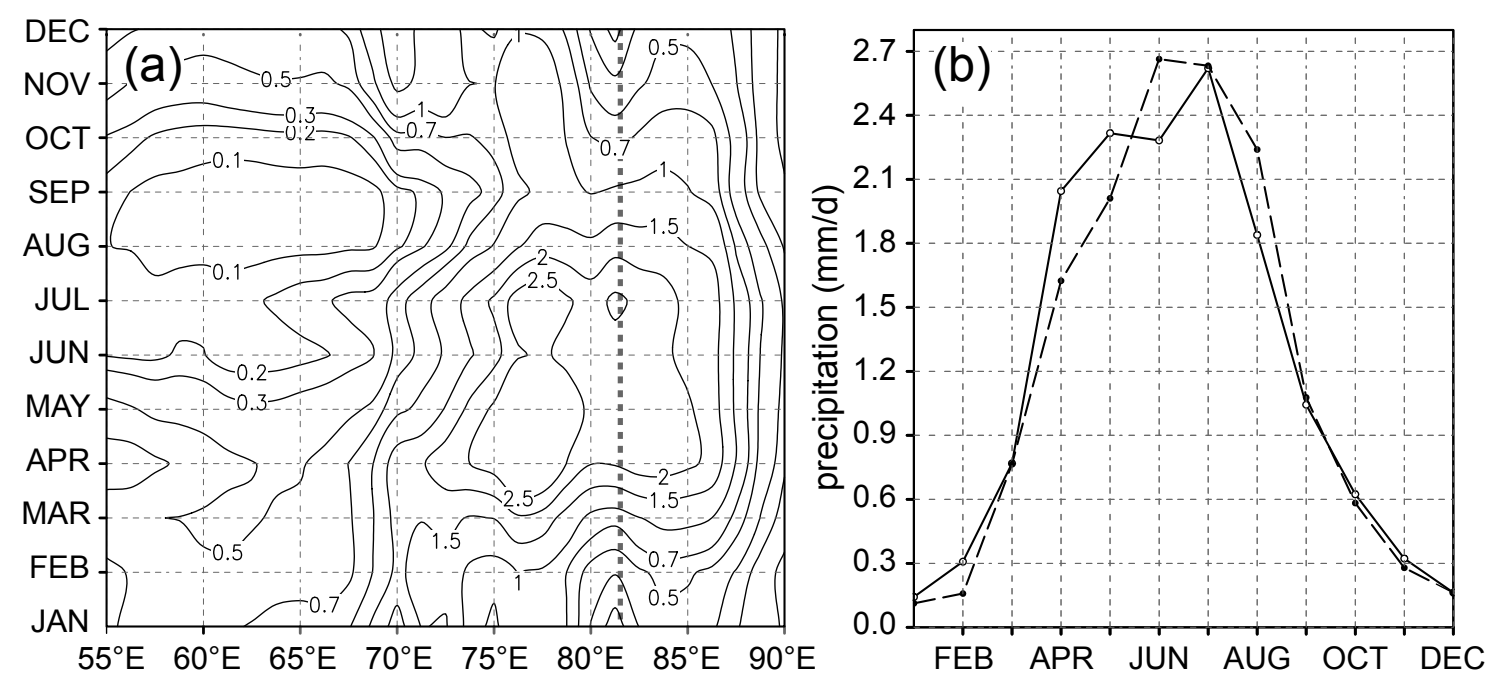

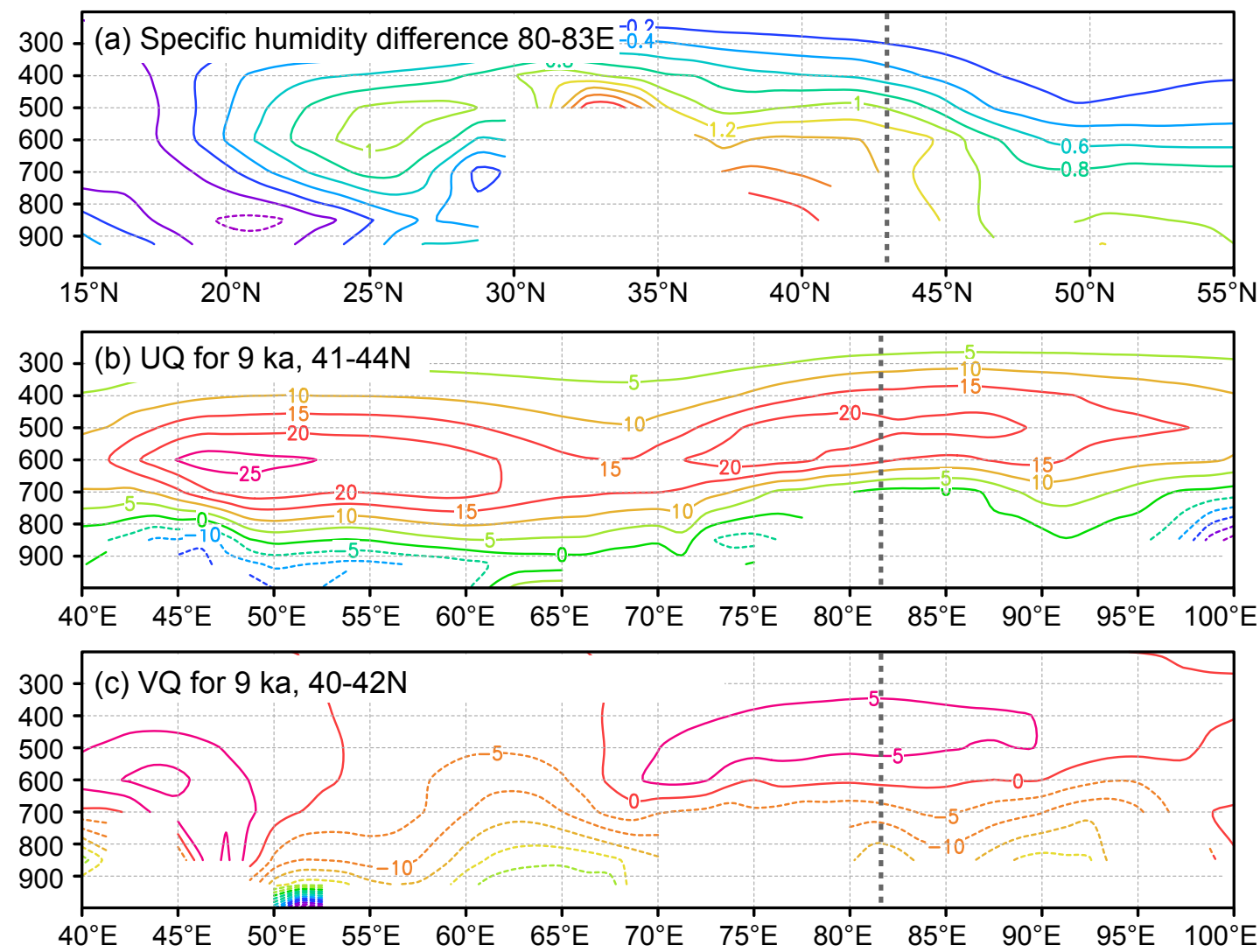


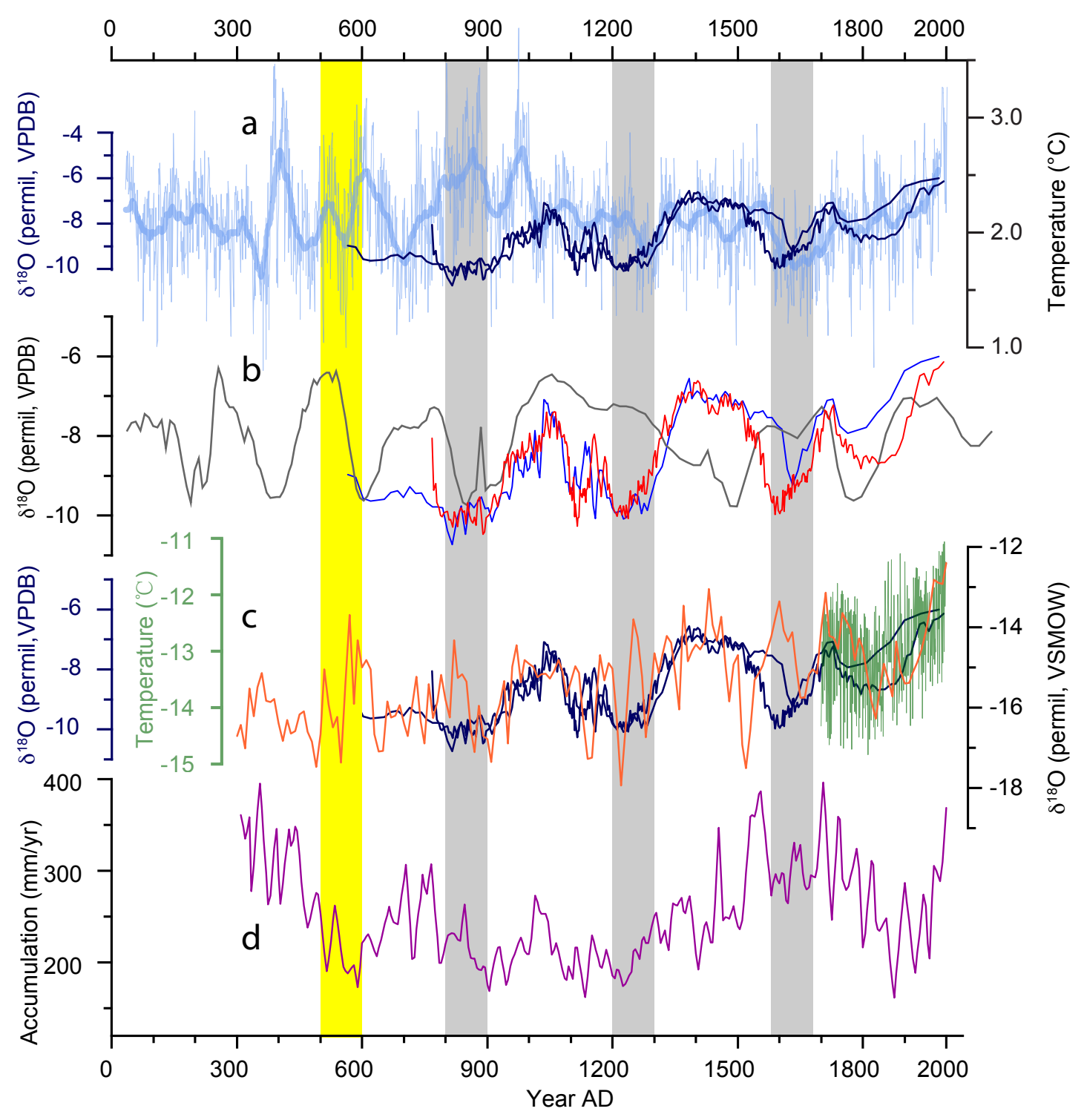

